


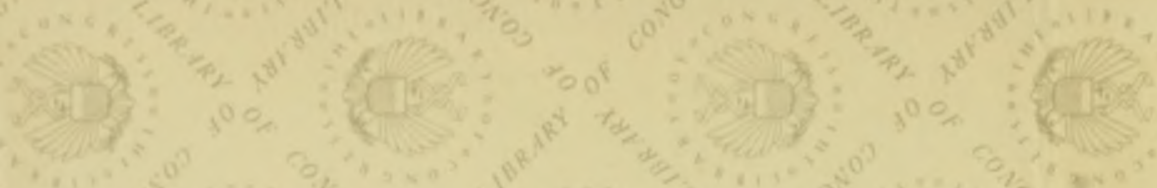

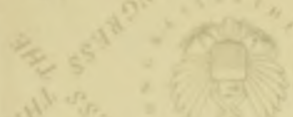

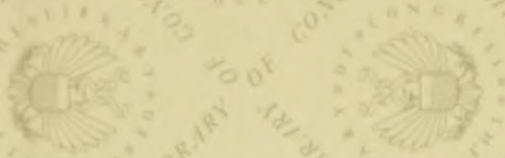
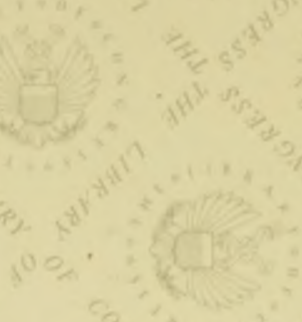

$$
003 \operatorname{los}^{2}
$$

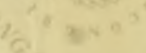
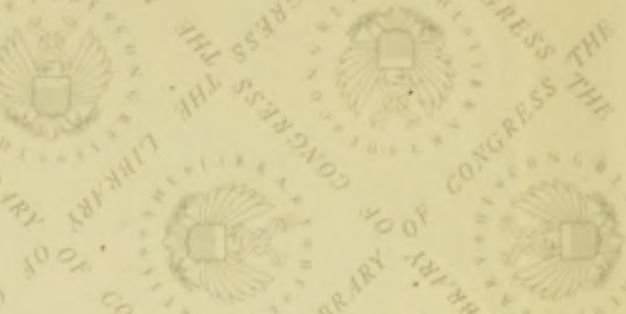

(2)

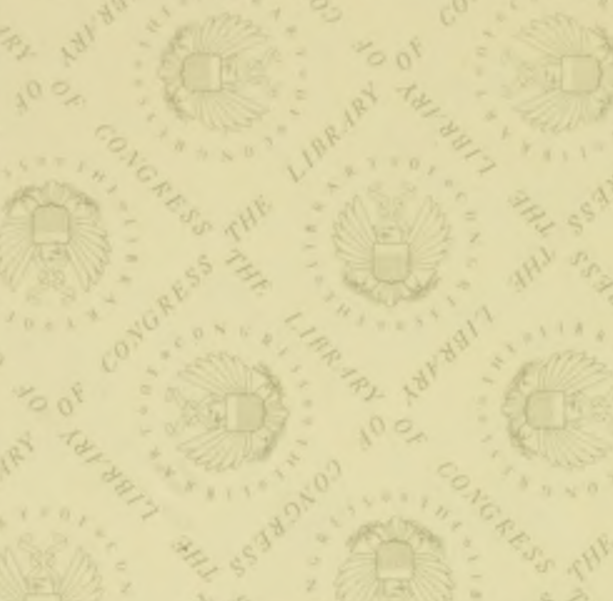

100

á

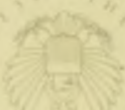

a)
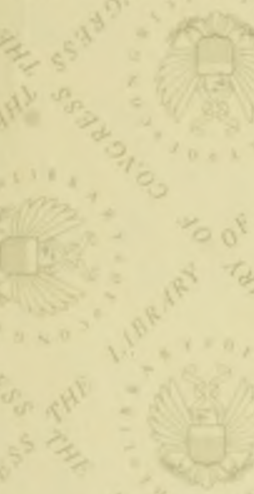

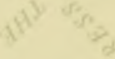

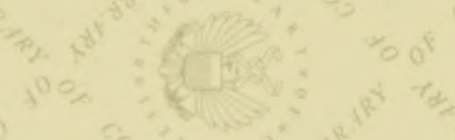

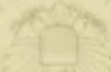

26

(4)<smiles>c1ccsc1</smiles><smiles>CCCCCCCC</smiles>

and ing

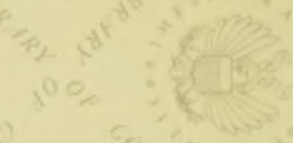

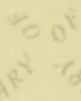

$(2)$

af 3

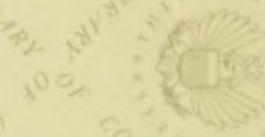

$2 x^{2} x^{2}=3$

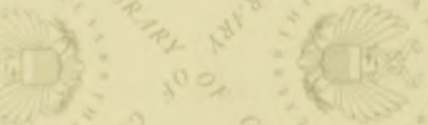

300

Wath

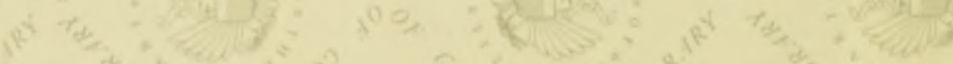

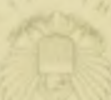






\title{
TROPICAL FIBRES:
}

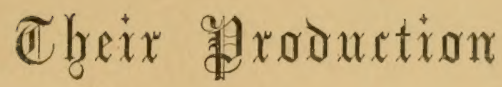

AND

\section{ECONOMIC EXTRACTION.}

BY E? G. SQUIEI,

FORMERLS MINISTER OP THE UNITED STATES IN CENTRAL AMERICA ETC,

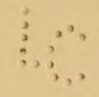

NEW YORK:

SCRIBNER \& CO., 124 GRAND STREET.

1861 . 
Entered according to Act of Congress, in the year 1861, B Y E. G. SQ U IE R,

In the Clerk's Office of the District Court of the United States, for the Southern District of New York.

EDWARD $0, J E N K I N S$, 3 Jrinter and Stereotgper,

20 Ховти Wrutus Street, N. Y.

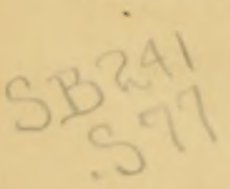




\section{INTRODUCTION.}

No person from northern latitudes can long reside in tropic countries, particularly in tropical America, without being struck with the number and variety of endogenous plants, such as the agaves, pine-apples, plantains, and palms, which form a characteristic and, to northern eyes, a novel feature in every landscape. If of an observant and inquiring turn of mind, the traveller will soon be brought to reflect on the economic value of these plants, and their thousand useful applications in supplying human wants. He will discover that they not only furnish staple articles of food, oil, and refreshing as well as intoxicating drinks, but also that they are the productive sources of valuable fibres, of every degree of fineness and strength, and fit for the most delicate tissues as well as for the strongest cables. He will find that the hammock in which he reclines is netted from a material almost as fine and soft as silk, and will probably be surprised to learn that it is supplied from the leaves of the wild pineapple, which he sees everywhere forming the hedges of enclosures, and scattered thickly through the forests. He will find the native boats rigged with cordage of superior description, and will be told that it has been procured from the agaves or hennequins, of which he will observe a small, perennial patch, with their green, fleshy leaves, growing by the side of almost every hut. Or, if in Mexico, he will 
receive his passport on paper of surprising toughness and durability, made from the leaves of the maguey - the juice of which, supplying here the place of beer, cider, and more potent whiskey, is sold in the shops over the way, under the name of pulque. Or if, in the East Indies, he desires to send home some souvenir of his travels, he will select from the stock of an itinerant pedlar, a handkerchief of gossamer-like texture, almost as fine and as delicate as that which the spider weaves, made from the fibres of the leaves of the pineapple plant, the fruit of which he ate for his dessert. If in Manilla, he will find ships of all nations filling out their cargoes with bales of excellent fibres, which he will mistake for hemp or flax, but which he will ascertain, on inquiry, are extracted from the stalks of the plantain-the forests of which, with their broad leaves, shadow over every path and by-road of the island.

And if our traveller be well-informed as to the wants of manufactures and the arts, he will wonder how it is that the acknowledged and increasing deficiency in the world's supply of fibrous materials, has not been filled from the numerous and prolific sources which he sees everywhere around him. $\mathrm{He}$ will, perhaps, be induced to inquire why it is that the millions of plantain trees which are eut down throughout tropical America, after having yielded their fruit, are suffered to rot on the ground, instead of being utilized for the excellent fibres with which they are lined. $\mathrm{He}$ will ask why the countless agaves, which sometimes surround him like forests, and the myriads of wild-pine plants which throng the woods, and invade every abandoned field, are allowed to send out their fibre-stuffed leaves to flourish and decay, while the world clamors for an increased supply of fibrous materials ?

Such at least, were the inquiries which pressed on my mind during my residence in tropical America. I saw around me 
alundant, I had almost said infinite sourees, from which to supl'y the existing defieiencies of the world and its future demands in respect of vegetable fibres. I asked myself, wonderingly, "Why are not all these fibre-bearing plants with which the country teems, in some way utilized?" But the question clid not recur, after I came to learn the rude, imperfect, and laborious processes by which the relatively small quantity of fibres produced for local use and export is extracted.

I saw the native laborers at their work, slowly removing the pulpy and vaseular portions of the agares or hennequins, with a triangular scraper, or a blunted knife, leaf by leaf, and ascertained that a few pouncts of fibres, imperfectly cleaned, formed the total reward of a long day's toil. I turned away from the patient Indian laborer with a smile, half of pity, half of contempt, and asked my friend, the American merchant and planter, who had lived for many years in the country, "Thy don't you import proper machinery for doing this simple work, and thus make a fortune out of tropical fibres?" "Because," mas his answer, "there is no such machinery to be had! I long ago sent to the United States, to England and France, and even to the P'hilippine Islands, where ten millions of dollars' worth of plantain fibres are extracted annually, and found that no machinery snited to the purpose has yet been invented. Everywhere, as far as I can learn, throughout tropical America, aud the East Indies as rell, the process of extracting these kinds of filnres, is substantially that which you see practiced by yonder Indian."

I was incredulous as to my friend's assertion, and when I returned to the United States I inquired for myself, but only to find his statement confirmed. I ascertained that although rarions machines had been devised for the purpose of cleaning the filores of the pine-apple plants, the agaves, and plantains, 
economically and rupidly, none had succeeded in practice.

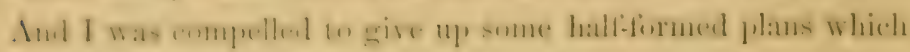

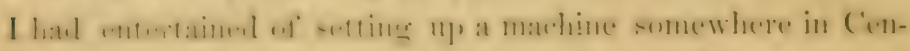
tral Americat, for the purpose of "making a fortune out of

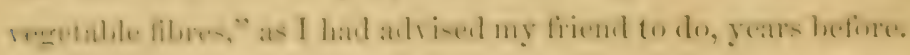

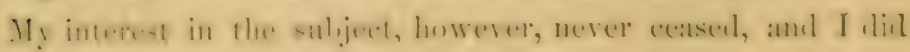
not entirely relinquish the notion, that sooner or later some rapid and eas methon of extracting the filores of the various

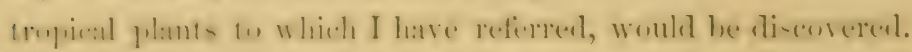
I therefore allowed mo intentions, claming to accomplish this

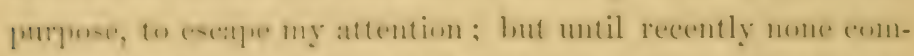

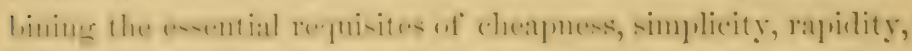

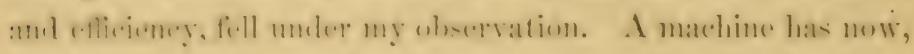
however, been inventel and put in operation, which, in my opinime combines the de-ired conditions, and which I hatre

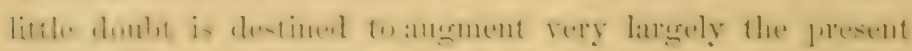

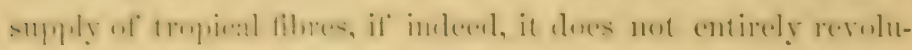

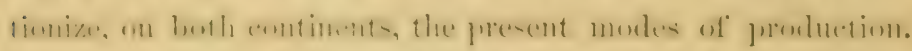

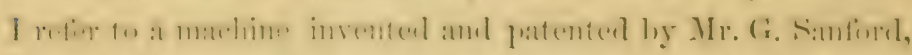

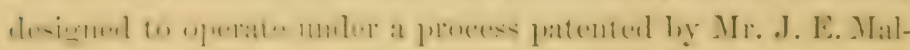
lory.

It is not my purpose here to go into any account of this

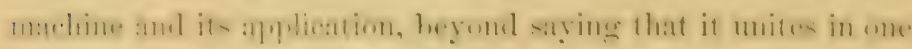
operation the various processes by which fibres are extracted manually, from the culogenous plants of the tropies. That is to say, it combines the processes of breaking or crushing, scraping, hateling, and washing, in one operation ; and I feel safe in sayine, that by the aid of a machine, not exceeding in enst \$100, one expert haud can extract in a single day; (say from the Alyare sisilunu or hennequin,) at greater quantity of fibres in better comlition, than one hunctred men ean obtain through the primitive morles now in use. Of its applicability 
to ermycuons plants and cortical fibres, such as hemp and flax, there can be no cloubt; but it is as a means of increasing our supply of foliaceous filores, and utilizing the myriads of tropical plants producing them, but now lost to the world, that it appeals to me with grentest force.

It is in this sense, and with a view of directing American enterprise to new and profitable fields of exertion, that I have lere thrown together the rarious fincts relating to regetable fibres, which I have collecter during the ten years since the suljject first arrested my attention. I lay but little claim to scientific aceuracy, either of classification or of expression; my object being to ardress myself rather to practical men of general intelligence, who may desire to enter into a new department of profitable industry, than to botanists. At this time particularly, when events have greatly circumscribed the sphere of Northern energy, skill, industry, and capital, and when the work is threatened with a deficient supply of cotton, the cuestion not only of olntaining cotton from other sources than the slave-holding States of America, but also that of increasing our suply of fibrous materials of other kinds, arailable for similar purposes, and of opening new fields for our enterprise and commerce-at this time, all these have become questions of great, not to say vital, import. If the information which I have before brought togefher, in comection with the olportune invention to which I have alluded, shall in any way assist in the solution of these pregnant questions, my object, in this publication, will be fully met. 



\section{TROPICAL FIBRES.}

\section{CHAPTER I.}

\section{EXTENT OF CONSUMPTION AND MODES OF EXTRACTION.}

Is their primitive condition, men clothed themselves in the skins of wild beasts, but when they "multiplied on the face of the earth," they were obliged to supply the deficient resources of the animal, from those of the vegetable kingdom. As they advanced in civilization, the thousand useful applications of vegetable fibres, not alone for clothing, but for cloth for tents, sails, and cordage for ships, and materials for paper, became gradually apparent, affording scope for invention and ingenuity in the arts, and employment for millions of human hands in the departments of production. and manufacture. No one need be told how widely and intimately the production, manufacture, distribution, and sale of cotton, enter into the industry and commerce, and eren into the social condition and political relations of the world at the present time. The story of its importance is told in the crash of the 300,000 busy looms, and the dizzying whirl of the $30,000,000$ of spindles of the British Islands, as well as in the lium of the less numerous but not less active manufactories of our own country.

But cotton by no means supplies, nor does it admit of 


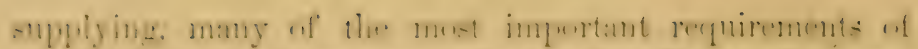

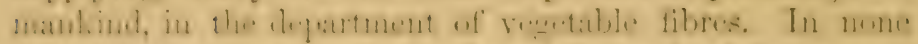
of its applinations, an it cynal in limeness the delicate cann-

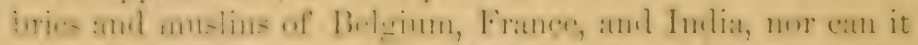
i.e une for the coare hut pworful cordage with which the thate of the worlil are rigent. The supply of filnes for

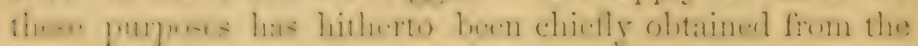

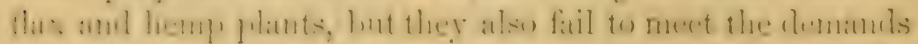

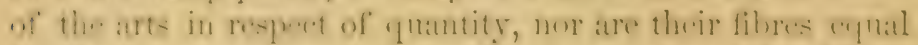
in otier important reyuisites, such as strength and dumblility,

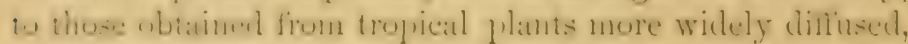
more economical, and casier of production.

Imberl, the smply of vemetable fibres from all sompers, does not meet the fresent and increasing demands of mantfir.ture, and many of the most important articles of eommen nse, such as paper, are steanlily alvancing in price, from an absolute and growing deficiency of fibrous materials.

Whenee is this delieleney to lie supplied? is a rne-tion

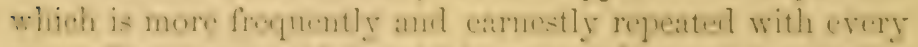
stowaling year, and to which no satisfactory answer hats

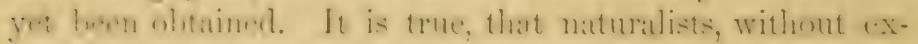
wption, have always printerl to the trophes, with its numer-

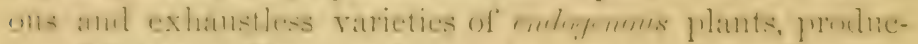

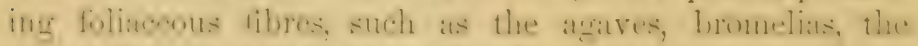

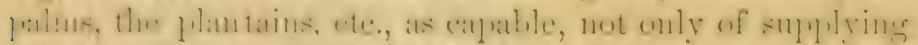

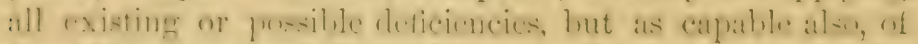
fumithing new and heantiful, as well as cheapl materials,

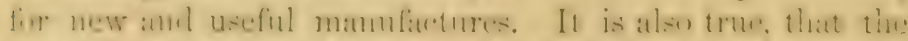
pombotion of tibres from tropical plants lats of late years

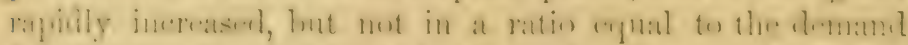

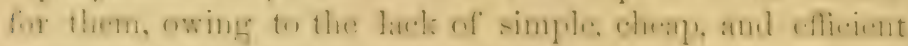
machinery for extracting the fibres. Some notion of the

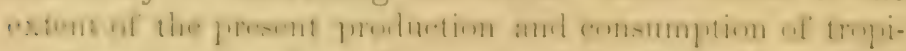
call fibres may be formed from the following tables, which show the amount and value of such as are imported into the Lnited States and Great Britain. It will be remembered, that these amounts are irrespective of those consumed by

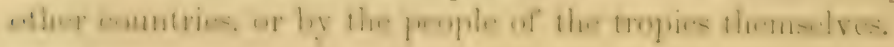


TAmre I.-Tropical Fihres imported into the United States for the year 1860. (Custom-house valuations.)

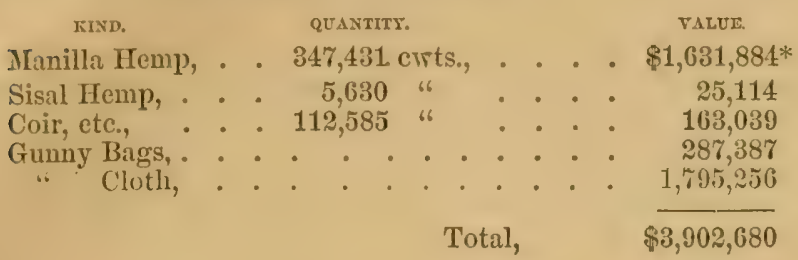

TAme II.-Tropical Fibres imported into Great Britain for the year 1855. (Estimated real value.)

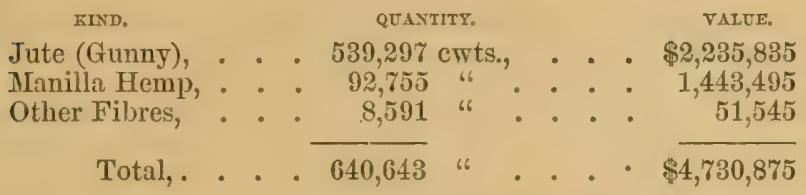

Considerable, therefore, as has been the production of tropical fibres up to this time, yet the amount has been insignificant, considering the practically illimitable sources of supply. The deficiency has resulted, as we have alreadly had occasion to remark, from a lack of proper and economical machinery for separating the fibres from the pulpy and woody matcrials, and the salts and gums with which they are mixed in their natural state. As will be seen when we come to speak of the production of Sisal and Manilla hemp, and of Inclian fibres in particular, all the processes for extracting them, at present in use, are to the last degree primitive and inefficient.

The native of Yucatan, in order to obtain the material known as sisal hemp), laboriously splits open each leaf of the hennequin plant, and then serapes and rubs ench section

* It will be seen that the raluation of Manilla hemp in the custom-houses of the United States, according to the returns, is only about $\$ 470$ per cwt., while according to the consular returns from Manilla, the original cost there is $\$ 8$ per ewt. The English official returns are computed on the estimnted real value at the port delivered, and give this hemp a valuation of $\$ 1125$ per ewt. At this rate, the value of the import of this article into the United States for the year 1860 , would be $\$ 3,908,848$, instend of $\$ 1,631,000$. 


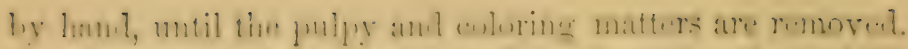

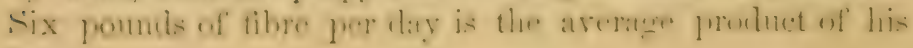
labor:

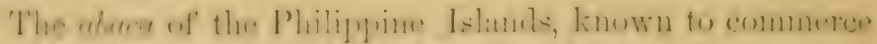

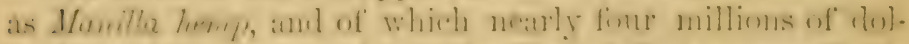
lare' routh are inportul into the [nitud states anmally, is

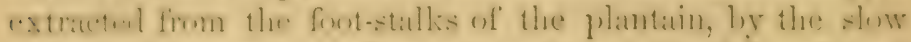
and prisutive grons: of foumling them with cluhe of harel

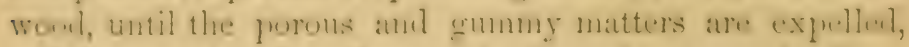
and then passing them fropuently through a comse hackle.

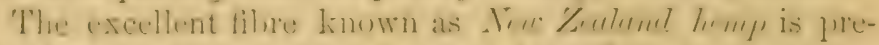
garen from the laves of a plant of the Jily family, either by bating them with mallets, or by a long and damaging process of drying, maceration, and hackling.

In Inlia, where the natives, for centuries, have been accustonei to extract the filores ly the injuriens process of rot-

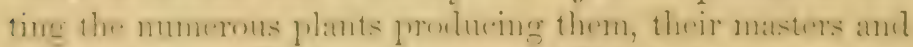
in-truetore, the Fuglish, as late as 155.5, hawl no letter in-

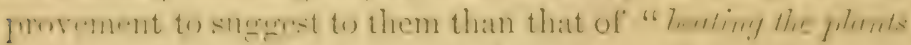
with a mallet, and then scraping them, in small handfuts at a time, on a board, with a blunt table-knife, or a long piece of hoop iron, fustened in a straight handle."

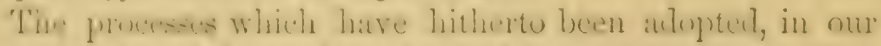

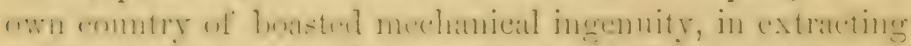

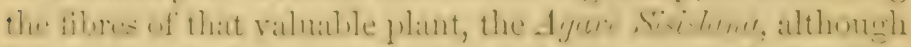
in alvane of those practied in other comtries for similan

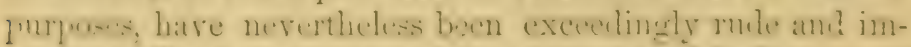

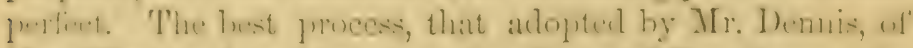

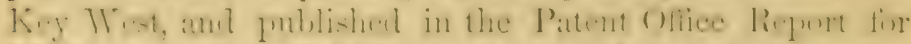

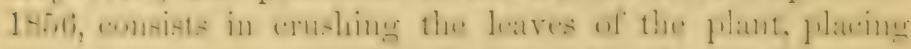
them in an open-work box to be washed by the flow and wob of the siat firr sereral ditys, and then beating them with sticks so as to clenn the fibre.

It may be laid down as an invariable rule, that any procoes for the astration of regutable filmes which insulves fermentation, or what is known as rolliny or relling, not only

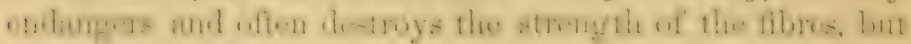

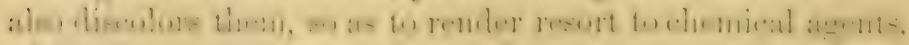

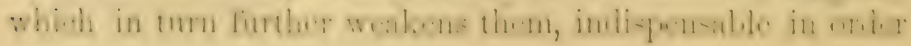


to bring them back to the whiteness which they possess naturally, if extracted at the proper time and in the proper manner. On this point we camnot do better than adduce the testimony of D1. G. T. Schaefler, whose acquaintanee with the subject qualifies him to speak with authority. Me says: "With fibres drawn from plants of full activity of growth, in hot climates, the danger from excess of fermentation becomes serious, for a few hours here may do damage which elsewhere it might require many days to oceasion. It must be remurked, too, thet many, if not inded most fibres, require for the attaimment of a proper degree of softness and delicacy, to be gatheretl before the full maturity of the jolunts to uchich they belony. In proportion as this period is anticipated, will the nitrogenous or fermentable matter be present in greater quantity."

Now, it has been ascertiined, and the process of Mr. Mallory, referred to in the Introduction to this Memoir, is based on the fact that nearly all, if not all the fibres of the vegetable world are white, while the plants producing them are in their green or growing state, and that they are only discolored by the sap which holds the gummy and coloring matters of the plant in solution when the latter ripens and begins to decay, or by being exposed to the sun's rays. Natural or artificial heat has also the cifect, more or less deciled, of fixing the coloring matters of plants in their fibres.

It is true, that the use of alkalies in treating fibres, either with or withont pressure, in the process of boiling, will take out much of the gummy and coloring matters which they contain, but the heat will fix or set that which is left of a buff color, of greater or less depth, according to the strength of the alkaline bath used. This color is extremely difficult of extraction. If a strong solution of caustic alkali is used for the purpose, with a great degree of heat and pressure, the filores become greatly expinded, and enough of the coloring matter will be destroyed to render the fibres of a light gray color, which, however, it will require the use of chlorine to get ricl of entirely. It is easy to see that such processes for obtaining fibres perfectly white, are not only expensive, but damaging to the fibres themselves. 


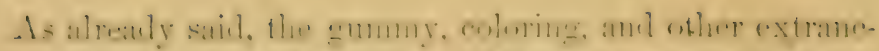

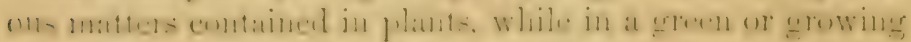
state, are soluble in cold water, and may be removed by

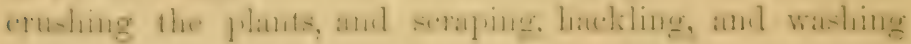
them-a compound process which the machine, to which

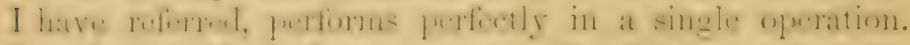

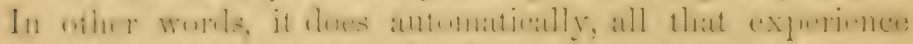

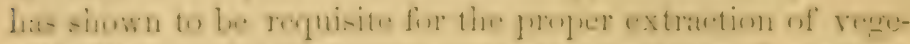

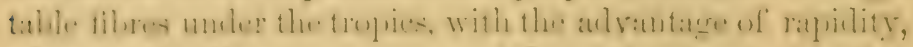
wherely the thems are frestred from the chemical action of the atmosphere.*

* The gum held in solution in all plants while in their green or growing stnte, when dried into the fibres, renders them harsh, brittle, and more or less unfit for paper and textile purposes. It has been grenerally believed that the difference in appenrance and degree of softness of the various kinds of filces is owing to their difference in mature; when, in fact, the real difference in softuess is grenerally due to the greater or less amount of gum still remaining in them.

Experience las proved that Manilla hemp makes excellent paper, and the only objection raised hy paper makers to the general use of this stock, is its harshuess and the diflieulty of bleaching it jerfectly white; all of which oljections are now removed by the use of the Mallory process, with the aid of the Sanford machine. I have recently seen some of the plantain fibre or Innilla hempe extracted under this process and by this machine, which eame out almost perfectly white and nearly as soft as silk-proving, beyond a doubt, the correctness of the theory and practice deseribed above. 


\section{A P TER II.}

\section{FIBROUS PLANTS OF AMERICA AND THE EAST INDIES.}

OF tropical fibrous plants, $\Lambda$ merica produces indigenously her full share. Those of the pine-apple fumily, from which the delicate fibric known as pina is manufactured, are peculiar to this continent, although they have been introdueed on the old continent, where they flourish in such numbers as to constitute an important part of the Flora of the west coast of Africa, and of portions of the East Indies.

The Brometia syliestris, or wild pine-apple, which produces the silk-grass of the British TVest Indies, and the filc of Mexico and Central America, and which, from its hardy mature, luxuriant growth, and abundant and excellent fibre, seems entitled to rank first among all the fibre-producing plants of the tropical world, (the plantain possibly excepted,) is still only found in its natural hatitat, although there is $n$ o doubt it could be readily propagated in corresponding latitudes, all over the globe. All varieties of the Nluse or plantain family produce good fibres, and experiment has shown that the peculiar varicty which yields the celebrated Manilla grass, (Muse textilis,) although indigenous to the East Indies, nevertheless flourishes in tropical America and the Antilles, in as great luxuriance and perfection as in its mative soil. The agares, too, perhaps the largest as they certainly are, taken collectively, the best and most abundantly protucing fibre family of the globe, in their cenomic rarieties, are also peculiar to America. The Agure Americance has been introduced into the southern part of Europe and into Algeria, and seems to flourish sufficiently well to justify the belief that it may ultimately contribute its share to the fibre erop of those countries. Its brothers, however, the useful Agave Mexicana or marney, and the invaluable 


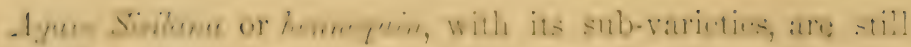
peculiur to this continent. It is from the latter that the

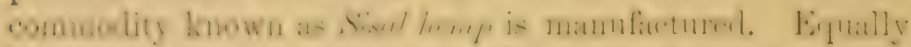

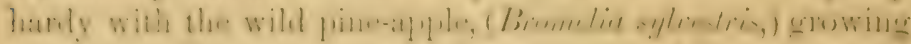
well in every variety of soil, amongst rocks, and in arid wastes whore aluost every other form of veguable life disappar ant prokneing an ahmulance of exwellent filmes, it offeris a soure of sipply of librons material, unkler an any and anemente methoil of extraction by mathinery, only to be limited by the publie demand.

Leaving out of view, for the present, the fibre-bearing flante of thr falm, lily, and serew-pine families, we cin-

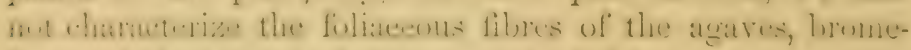

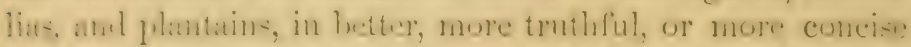
Janguage than that of a man who, before his smliken and molatmbly drath, hat devoted nany years of an actire life to their.study and utilization:-

"lighter, strongrer, more olatic; aml more durable than

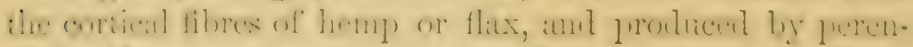

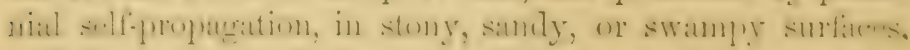

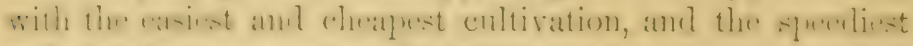

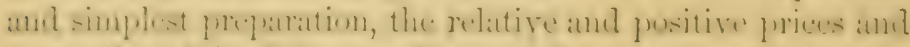

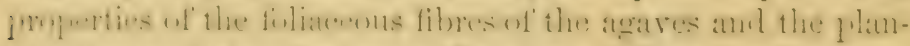

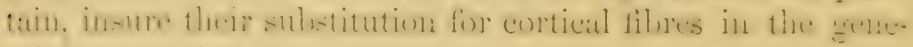
ral consumption of mankind."

- Letter of Dr. Ifenry Perrine, Consul of the U. S. in Tueatan, dated Campenehy, Nor. 24, 1834, and direeted to the Secretary of State of the Lnited State: In making this referenco, we should do injustice to the memory of a wise, sagracions, and patriotic man, if we omitted to notice the effurts of Dr. P'errine to introduce the enltiration of the fibrous-leaved plants of the tropies into the United States. During his longr residence in Campencly lo became aequanted with sho manner of growth of these plants, the modes of cultivating them, and the means of extracting their fibres, and conceived the idea of naturalizing them in the Sonthern States. Ilaving satisfeel himsedf of the practienbility of the enterprise, he petitioned Congress in 1897 to nid in enrrying it out on a large seale. His npplication was suceessful, nucl Congress passed a hill, giving to him and his assoeintes, under the name of the "Tropical I'lant Company:" the pre-emptinn right to thirty-six soctions of lamel situnt ed in Fast Florida, leclow the parallel of $26^{\circ}$ north latitude. Small plantutions were nt une commenced at Cinpe Florida, and other perints in its neighborhood, into which a variety of plants from Central smeriea were intro. 
The agares and bromelias, indigenous to this continent, supyly better substitutes for flax amel hemp than any of the olel-world plants, while the fibre of the banama or plantain can be proluced here in as great perfection, and with as much ease, as in the Philippine Islankls, or any other part of the East. Yet, as will be seen by reference to foregoing tables, the United States imports amuully nearly four millions of dollar's' worth of East Indian fibres, against less than one humired thousand dollars' worth from the tropical regrions of America. This is, no doubt, in great part clue to the circunstance, that manual labor is cheaper and more abundant in the East than in America, and that conseruently fibres can be more cheaply and abundantly produced there, by the slow and laborious band-processes hitherto in use. But if the sreat desideratum of simple and eflicient machinery for separating foliaceous and other fibres can be met, there is no doubt that our supplies would be obtained nearer home, in greater abundance and at less cost than is now possible.

The celebrated Spanish naturalist, Don Ramon de la Sagra, has giren a list of plants, which are suitable for cloth, indigenons to Cuba, with their local names. Leaving out cotton, I subjoin the list, with such information regarding the respective plants as is accessible.

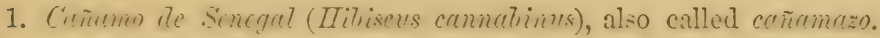
The conree chth made from it is used in some parts of the island for

duced. Among these rere three or four species of the agare, incluting the rarieties producing the sisal hemp, the maguey or fulcue agave, the cochineal cactus, paper mulberry, date palm, etc. All these succeeded well, and the enterprise fromised the hapliest results, when the hostilities of the In-

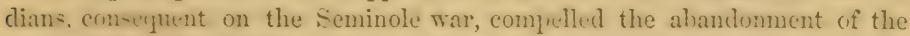
plantations. Dr. Perrine, however, whose whole soul was deroted to his undertiking, returned, after an interval, and was sulwecquently killed by the savages. The plants were then neglected, and many of them destroyed; but those that ware left have flourished and propugated themselves extensively. Although he did not live to see the fruition of his plans, Dr. Perrine, nevertheless, established the fact that nearly all, if not all, the fibrous plants of Central Aneriea and Mexico flourish freely in the Peninsula of Florilta, as they no dombt would also flourish, if introduced into the adjacent states to the northward. 
chothing the fitves, and is called colcta. The fibro is that known in India as sunnee, or sun hemp). Seo . Maleu, or Mfullow fiemily.

2. Civilu (Jimlute ceilua), or silk-eotton tree, producing a varicty of . cotton, only useful for stulling pillows, ete., the fibres not adhering to ench other. It is said that this product las been used in making liats.

3. Chichicustre (Urlien Zuecifire), a' wild shrub, of tho Urtica, or Fetule funily, also ealled clichicute. See Urtiea, or Netlle fumily.

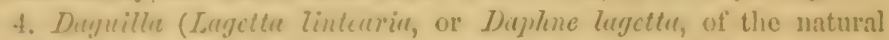
- orler Thymelet), is a forest treo, growing to the height of thirty feet, and two feet in thickness. Its imer bark, when cut in thin pieces, after naceration assumes a beautiful net-like appearance, and is used by the natives for aprons, collars, caps, etc. Its fibres are also used for cloth and cordage. 'The bark of many of tho plants of this family is made into ropes and paper. Specimens of the lace-bart here lescribed are often seen in the United States, in tho form of bands around bunches of Havana cigars.

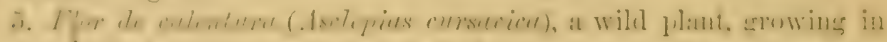

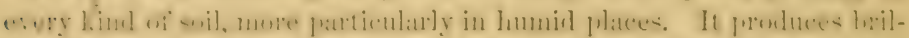

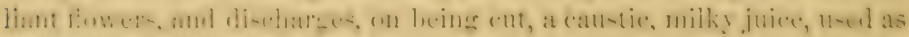
a purgativo in medicine. Its bark is fibrous, and is made into cordare. Tho Jelce, or Tongouse fibre of Madras, is from the stems of Asclepins linecissimu, a member of the same natural order, if not the same plant with the alowe.

6. Guumú, or Giambusino (Lonchocarnos tenax). See Lequminoser.

7. Guizuzo (Triumphita Semitrilota et Ularanense). Sce Tilia, or Lime-trce fiemily.

8. Jugney (Ficus indica). Seo Urtica, or Nettle fumily.

9. Mujüyur (Hilixens tiliaceus). Seo Mulvu, or Mulloro fitmily.

10. Muleaté (Curchorus siliquosus). Seo Tilinecer.

11. Pen de IFono (Adiensonia digitata ; Natural Order Stcreuliaccer), the Banbab treo of Senegal.

12. P'iñr (Bromeliu anunas). See Bromeliu fumily.

13. P'iñulla (Bromeliu pita, or karatas?) See as above.

11. Pila (Furercal fiutida?) See as above.

15. I'iln de Corojo. See I'ulm family.

16. P'latano. See Mrusa fimily.

17. Quimbombo (Hibiscus csculcntus). Seo Malra, or Mallon fimily.

Secman, in his "Botany of the Isthmus of I'anama,"

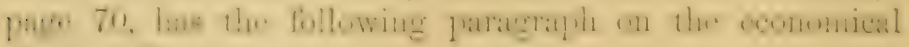
fibres of P'anama :

"Tho cordnge which tho people of the Isthmus use, is solely prodneed from indigenons plante. Tho hest and whitest roperis mado from the fibre of the corteal, (Apribe Tibourben, Nat. Orel. Tilincer.) 
A brownish louking rope easily affected by dampness, probably becansc the tree from which it is taken lits saline properties, is manufietnred

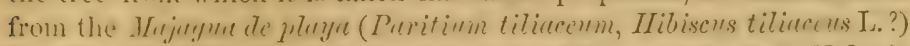

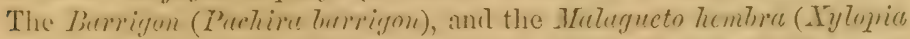
fintexens), also yields il filne fit for ropes. The liammocks of Verangas, consist of the fibres of the Cabuya (Agave sp.), and those of a palm called Chonta. A strong fibre is contained in the leaves of the Pita de zapateros (Brometia sp., which is prepared like flax, woven into bags or chacarces by the different Indian tribes, and extensively used by the shnemaker's for sewing. The fibre surrounding the wood of the

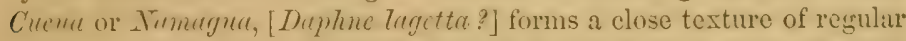
natural matting, which the natives soak in water, beat, and make into garments, beds, and ropes, or use as sails for their canoes. The mats which the poorer people sleep on, are made from the fibres of the plantain."

The East Inclies, although by no means as rich in fibrous encturgens, as tropical America, is nevertheless rich in exrogenous plants, producing useful and abundant fibres, of which Great Britain imports annually upwards of $\$ 3,000,000$ worth, and the United States, upwards of $\$ 1,000,000$ worth ammually. The processes employed in extracting these various fibres are cxceedingly primitive and slow, as will appear from the following descriptions, and warrant the belief that with cheap and simple machinery, the present production could be increased ten-fold.

The usual process followed for preparing the fibres of succulent, fleshy plants, consists in cutting them when in full vigor, and burying them in wet sand on the banks of a running stream, or in mud at the edge of a pool or tank, and leaving them to soak, or rot for one, trvo or three weeks, accorling to the temperature of the weather. The plants are then taken out, dried in the sun, and beaten with heary sticks on the dry hard ground, and rell rubbed between the hands to separate the chaff and dust. Another method is to take the soaked plants in bundles, and beat out the pulp and impurities on a flat stone, at the edge of a tank or on the shores of a river.

The fibres of the Ifroot, (Stuserierce Zeylaniea) are ob. tained by scraping and washing in fresh water, soon after the plant is cut. Those of the Yercum, (Cututiopis gigentene) 


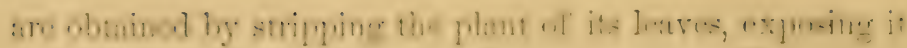
to the sun for several days, and then peeling ofl the bark

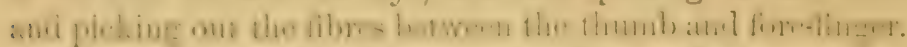

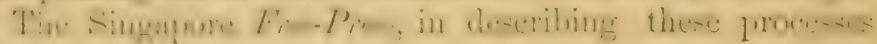
very justly observes:-

"The system of cleaning fibres by rotting is not suited to warm climntes, innsmuch as putrefaction sets in almost as soon as fermentation; and while one part of a henp of stalks is beginning to ferment, another part is staned from putridity, whilo the central parts remain fresh and unaltered. To preserve the color and strength of the fibres it is ncecssary to scparute the pulp, bark, or vcood, as soon as prossible, and by the least complicated process. The pulp or juices of plants usually contain mucilage, stareh, or gum, which begin to ferment within twentyfour hours after the plant is eut; and if they be left in water during warm weather, fermentation is completed within two or three days. In cold climates it takes as many weeks. Tho result is that the sap becomes acid, and destroys the strongth of the fibre. This is followed by putrefaction, which not only stains the fibre, but makes it brown and hrittle.

"If the plant is left exposed to the sun for a day or two after being cut, the sap dries, and the coloring matter stains the fibre, which cannot then bo easily separated from the bark, spiral cells, nor woody materials. In some plunts this discoloration is green, in others brown or dnsky yellow, which cannot be removed by bleaching, as it is a species of natural tanning inherent in the plant. Such fibres always remain stift, harsh, and woody, with a tendency to snap on a sudden strain. The plantain fibre (Manilla hemp, ) is liable to this defect,

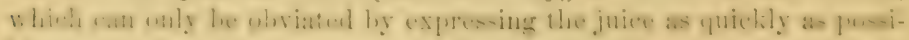
ble, and only cutting as much of the plant as can be cleaned in a single day.

"The proper mode of cleaning the fibres of pulpy plants is to crush them between rollers, those of the common sugtur mill will answer; and while the fibres are in this condition, seize them at both conds, and twist then in opposite ways to squeeze out the sap. They are then to be well washed in water, untwisted and seraped, in small handfuls at a time, on a board, with a blunt table knife, or a long piece of houp iron, fistened in a straight handle. When all impurities lave been romoved, the fibres shomld be sonked for an hour or two in clean water, ant then humg up in the shade to dry. Fxposure to the sun, at first, is apt to discolor them. J3y this process fibres of great strength. of a silky appearance and foond color, con resulily he proeured. The serapings should he well washerl and put aside in the shade to dry as tow lor packing or as materials for paper."

"The Indinn plants, to the cleaning of which this process is applica- 
ble, are thoso of a fleshy or pulpy nature, such as tho aloc, agave, sanseviera, and plantain genera, of which there are many species. The prices in England for Indian fibres thus cleaned, vary from \$125 to \$3:30 per ton; while the same fibres, cleaned by the rotting process bring, only from $\$ 60$ to $\$ 90$ per ton, and are said to be only suitable for the manufacture of coarse twine, or brown packing paper. The finest plantain fibre (Manilla hemp), when carcfully eleaned and dressed, is satid to be suited for the imitation of silk in carriage-braid and carpet work. Its average value is $\$ 250$ per ton, while liussia hemp is selling at $\$ 200$ per ton.

" Mauny of the Indian cordage plants are those haring bark and wooly filures, and the native process of cleaning is very similat to that of eleaning the plants already mentioned, viz. : by burying them in wet sand or mud, and leaving them to rot. There is this difference, however, that the plants are steeped longer, and are never exposed to the sun to dry. If this were done, the woody portions would get hard and brittle, and adliere to the onter fibre, which, being partially rotten, would break in the cleaning. To obviate this, the rotted plants are taken up in large handfuls and beaten on flat stones, first at one end and then at the other, in the same way that clothes are washed by washerwomen. They are next well rubbed and washed to separate impurities, and spread on the ground to dry. We ean hardly wonder, therefore, that most of the cordage made from fibres prepared in this rude, coarse way, should be dark in color, and of little strength and value. As a rule, every day"s steeping of a fibre takes from its strength and discolor's it. To obriate this, woody plants should be first well beaten with a mallet, and then the bark separated from the stalk, for it is on the inner side of the bark that the filores for cortage nsually occur. When the bark is brought to a pulpy state, it should be well washed in clean water, to remore as much of the sap as possible, for this is the destructive agent, which soon causes putrefaction."

Dr. Royle, whose work on cotton is well known in this country, has published a work on the fibres of India fit for cordage, which, however, I have been unable to consult. The following tables of the comparative strength of these fibres are from experiments made by Dr. Roxburgh in 1808, and Dr. Wright at a later period:

\section{According to Dr. Roxburgh's experiments:}

POPULAR NAME

Bowstring hemp,

Caloee hemp,

Sun hemp,
SEIENTIFIO NAME.

BREAKING WITHIT.

Asclepias sp............ 248 lbs.

Urtica nevia.............. 240 "

Crotalaria juncea........... 160 " 
$1 \ldots \ldots \ldots$

- I::a 1. III),

$11+1, i, 1$, ti:m!

Domcha,

.......

Musat paat,

Bunghi,

Plantain,

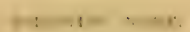

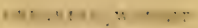

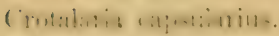
11:41).

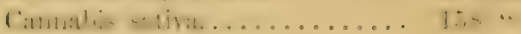

deschymomone canmbinus.... i: . .

Ilibiscus strictus. .......... 1\%

Mlibiscus cańnabinus........ 11. ..

Corchorus olitorius......... 11: "

Musa ...............

\section{According to Dr. Wright's experiments :}

DUVULAR: NAME

Iercum ทลг,

Jamapun or Sun,

C'atthalay nar,

C'otton,

Jarool,

Coir,
GCIESTIFIC NANE.

תREAKISG TEIGUT.

Calotropis gigantea........ 5.52 los.

Crotalaria juncea........... 107 ".

$\Lambda$ gare Americana........... 362 "

Gossypium................ 340 "

Sanseviera zeylanica........ 316 "

Hibiscus cannabinus......... 290 "

Cocos nucifera............ 224 " 


\section{CHAPTER III.}

\section{FIBRE-PRODUCING PLANTS.}

ALL vegetable fibres used for textile purposes, resolve themsclves into three great classes, viz.: Foliaccous fibres, Cortical fibres, and Capsular fibres.

1. Folicecons filres. These are obtained from Endogenous or ILonoctylatonous plants, or inside-growers, which are best known to us in their herbaceous forms, such as the grasses, including the cereals, sugar-cane, and the common cane, as also the lily, the cat-briar, and all plants in which the leaves have parallel veins. Uncler and near the tropies, the endogens are represented by the yuccas, the agares, the plantain, and the great family of palms. These plants do not form a regular bark, show no signs of annual growth, and do not increase by continual additions to the outsicle of the stem, as is the case with the trees common to our climate. Their fibres are imbedded in the cellular tissues and pulpy matter of their stems and leaves, and may in most, if not all cases, be extracted by a purely mechanical process. The fibres known as Manilla hemp, Sisal hemp, silli-grass, ete., are oltained from plants of this class. It is only in tropical and sub-tropical regions that endogenous plants attain any great development, take arborescent forms, or yield fibres suitable for textile purposes. To an inlabitant of the Northern temperate zone, an endorgenous plant of which the green leaves yield valuable fibres, is a curiosity only to be seen in conservatorics or botanical gardens.

2. Cortical fibres. These are obtained from what are botanically known as Exogenous or Dicotylettonons plants, or outsile-growers, and are contained in their bark or liest. They are often of great length, but little hardened, and with the 


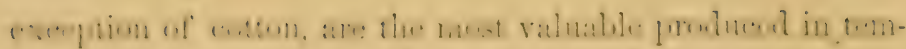
perate elimates. Some of the plants of this class attain

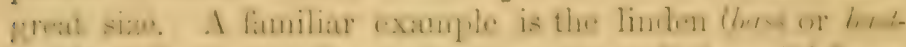

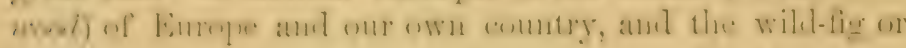
banyan tree of the tropies. A greater number, however,

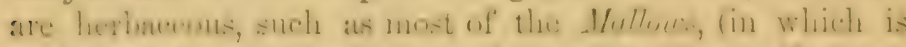

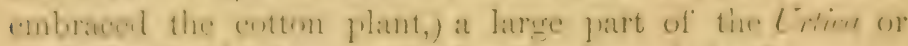

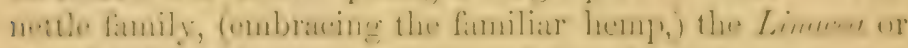
flas family, and some ratricties of the Lefrmimen or pleat

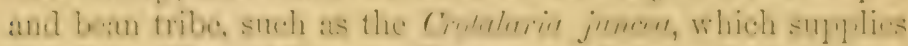
the Swe or lingal hempl. The stems of these plauts eourist of a womly come, sumomuled hy a sheath of filmons textume, ani the two are comeded hy a preculiat regetalile glue, which unites them in a solid st.m. In the preparation of flax, hem], China-gras:, cte, the olject is to remure this matter, and thus separate the useless stem from the valuable extemal sheath of fibres.

3. Cuppoular fulres. These, as the name indicates, are

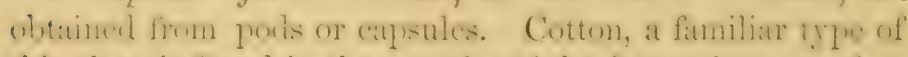

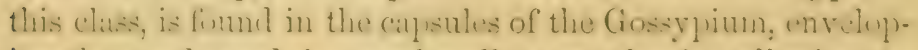
ing the seches, and in marly all cases closely allering to them.

It ith thase general olserrations, we proeed to notice the

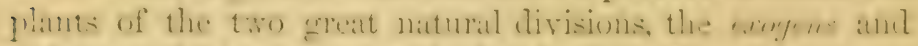

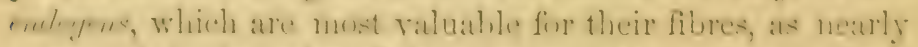

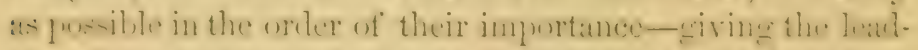
ine plawe to the emerms as exentially tropical, and ats

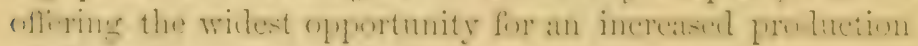
of fibres througl the aid of proper machinery. 


\title{
CHAPTER IV.
}

\author{
ENDOGENOUS PLANTS.
}

Six orters of the entogens yield fibres which are commercially valuable, viz.: 1st, the $\Lambda$ gave or $\Lambda$ maryllis fanily; $2 d$, the Bromelia or pineapple family; $3 d$, the Mrusa or plantain family; 4th, the Yucea or lily family; 5th, the Palm family; and bth, the Pandancer or screw-pine fumily.

\section{I.-Agave, or Airirylits Fanily.}

MLany of the plants belonging to this family protuce excellent fibres, in great abundance, and are indigenous in all parts of tropical and inter-tropical America, over a broad belt of at least $33^{\circ}$ on each sicle of the equator, from Virginia on the north, to Paraguay on the south. They are easily cultivated, hardy, and flourish equally in the richest and in the most sterile soils. Indeed, in thousands of places, where rocky, indurated, and sandy and arid soils prohibit every other hind of vegetation, the agaves find root and a vigorous growth. Several varieties are indigenons in the United States, such as the Algare Timinica, which is found in the worst soils from the Potomac to the Mississippi, ancl the d. vivipere, which is found in Florich, and perhaps in some of the other States fronting on the Gulf of M[exico. It is, however, under the tropies proper, throughout Mexico, Central Ameriea, the northern States of South America, and in the TVest Inclies, that the agaves are most abundant, and may be multiplied to any extent necessary to meet the demands of the world for the lind of fibres which they pro. duce. 
Sormal rarietice of the Mexican ant Contmal Aneriean

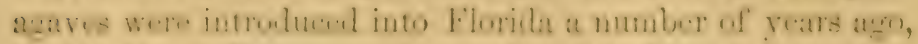

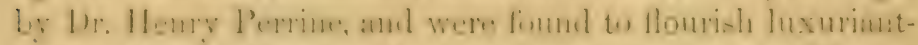
15: but the ir cultivation does not seem to have been followed

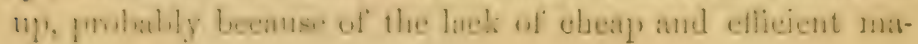
clinery for separating the fibre.

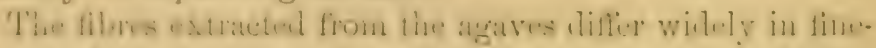
nese and con-riwent ralue, although all are artalable for

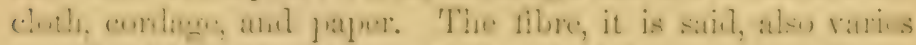

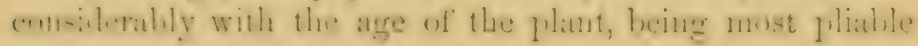
and easily worked if taken when the plant is young.

Supoudial writers and travellers have cancol great confir-

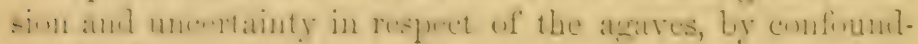
ing the litionnt speces, and their contralictions hatve nueh

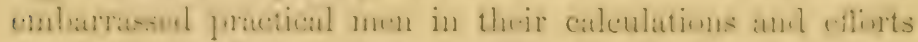
for miliming them. This mecrtainty and conficion have

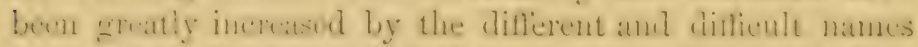

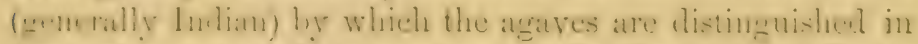
the rarions parts of the continent. In Mexice the dillerent

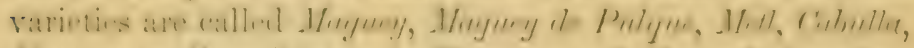

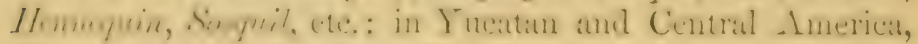
Hennequin, Cabullu, Pila, Yushqui, Sacqui, etc.; in Cuba,

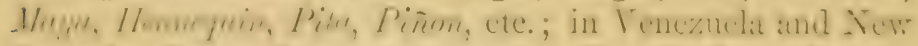

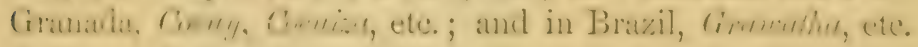
Great confusion also exists in the names of the fibres ex-

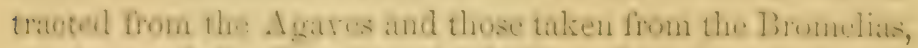

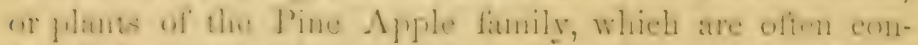

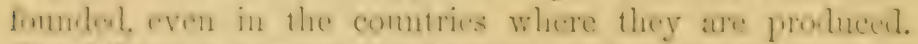
'The 6ullowing heriftions, howerer, will sirre to correct, in part at least, some of the mistakes in these respects.

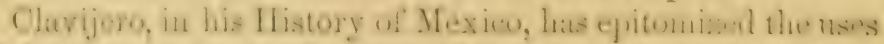
of the yuriumis limis of agnves of that eountry, in the fyllowing langunge:

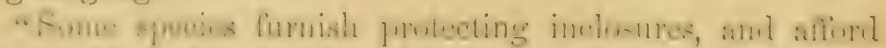

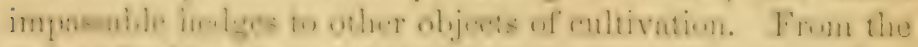

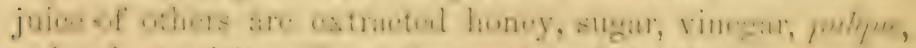
and andent mitits. From the trunk and the thickes part of

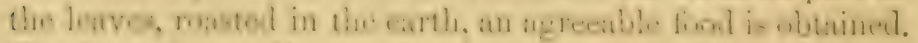

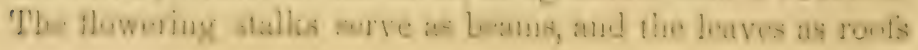


for houses. The thorns answer for lanects, awls, neclles, arrow heads, and other entting and penetrating instruments. But the fibrous substance of the leaves is the most important gift of the agaves to Mexico. Aceording to the species, the fibre varies in quality from the coarsest hemp to the finest flax, and may be employed as a superior substitute for both. From it the ancient Mexicans fabricated their threal and cortage, mats and bagging, shoes and clothing; and webs equivalent to cambric and canvas; the bammocks in which they are born, repose, and die; the paper on which they painted their histories, and with which they adored and adomed their gods. The value of the agaves is enlaneed by their indifference to soil, climate, and senson; by the simplicity of their cultivation, and by the fucility of cxtracting and preparing their products. It is not, therefore, surprising that the ancient MIexicans used some part or preparation of these plants in their civil, military, and religious ceremonies, at marriages and deatlis, nor that they perpetuated an allusion to their properties in the name of their capitol."

1. Agave Sisilana, so called from the city of Sisal, in Iucatin, whence the fibre, extracted slowly by hand, has found its way to market under the mame of Siscel lemp), or' grass hemp.

This plant, called Sosquit in Mexico, and Cutulle in Central $\Lambda$ merica, is indigenous in every part of tropical $A$ merica, and may be cultivated with the greatest ease, to any clesirable extent, as well on the very stony surfaces of the interior; as on the very sancly soils of the coast. There are two varieties, distinguished in Yucatan as the Yoshmi hennequin, which produeed the best quality of Sisal hemp, and the surpei lemmequin, which gives the greatest quantity. In Central Ameriea the fibre of both these varieties is called Cutullu, and is used for cordage; while the fibre of the Dirmirflin sylvestris, distinguished as quilu, is fine, and usecl for thread and cloth. Both are admirably adapted for the manufacture of paper of toughness and beauty.

Plute I, represents the Yustiqui variety of the 1 gene Sisit. 
une, after is first cron of lower leaves has been ent oft for

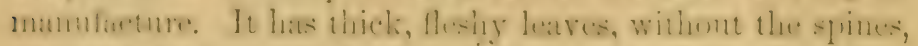

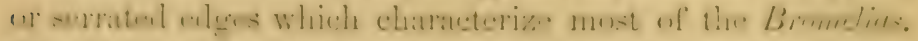
'They rary in length from five to twelve feet, and in width fom thro to five inches, the fibes ruming the whole leneth.

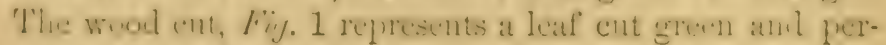
fect from the stalk.

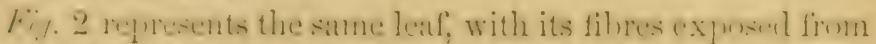

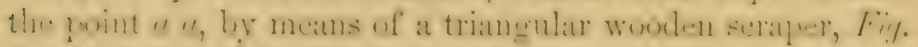

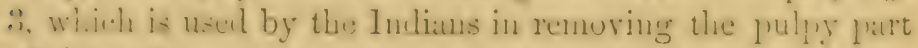
of the leaf.

l.i. 4 is a moteher wookn instrunent, user in splinting the leaf inte stripe, five or six in number, cach of whin is alderwat worked hy the triangular scraper, which is usul after the manner of a currier's shaving knife.

By this primitive process all the Sisal hemp brought to

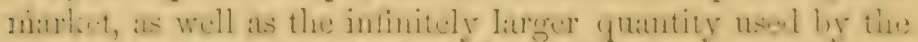
matives themselves, is slowly and laboriously extrated. The workmen obtuin only from tive to six pumbls ner day.

In the connunie:ation male to the gevernment by Dr. II. P'orim, in 16:34, and alrearly referrecl to, that whicer speaks of the Yushqui hennequin as follows:

"I berg the degartment to refleet on the fact that the very : tronge light, durable fibres of this plant, cxtractal fron the

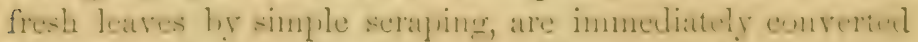
inte cheap cloth for bitgeng, cte, withont spiming, 1 wisting, or any interne liate freparation or falsication whatever. liy the inadruple proplerties mited in the single nutwisterl,

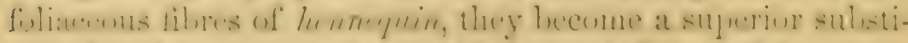
thte fir the cmmpund, twisted, cortical fibres of hemp, in the manufacture of many cotrse articles of extensive con-

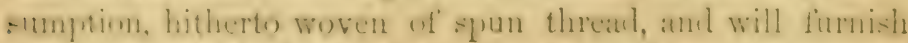
cheaper equiralents for lating ant envelopes in focteral, than any oflere lind of extrated fibres, or any wher material that on be woven, neted, matted, or litited, except

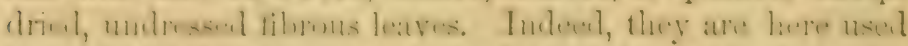

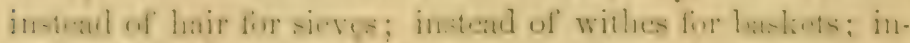
atcol of lenther and wowl ber ralises and trunles and even is 


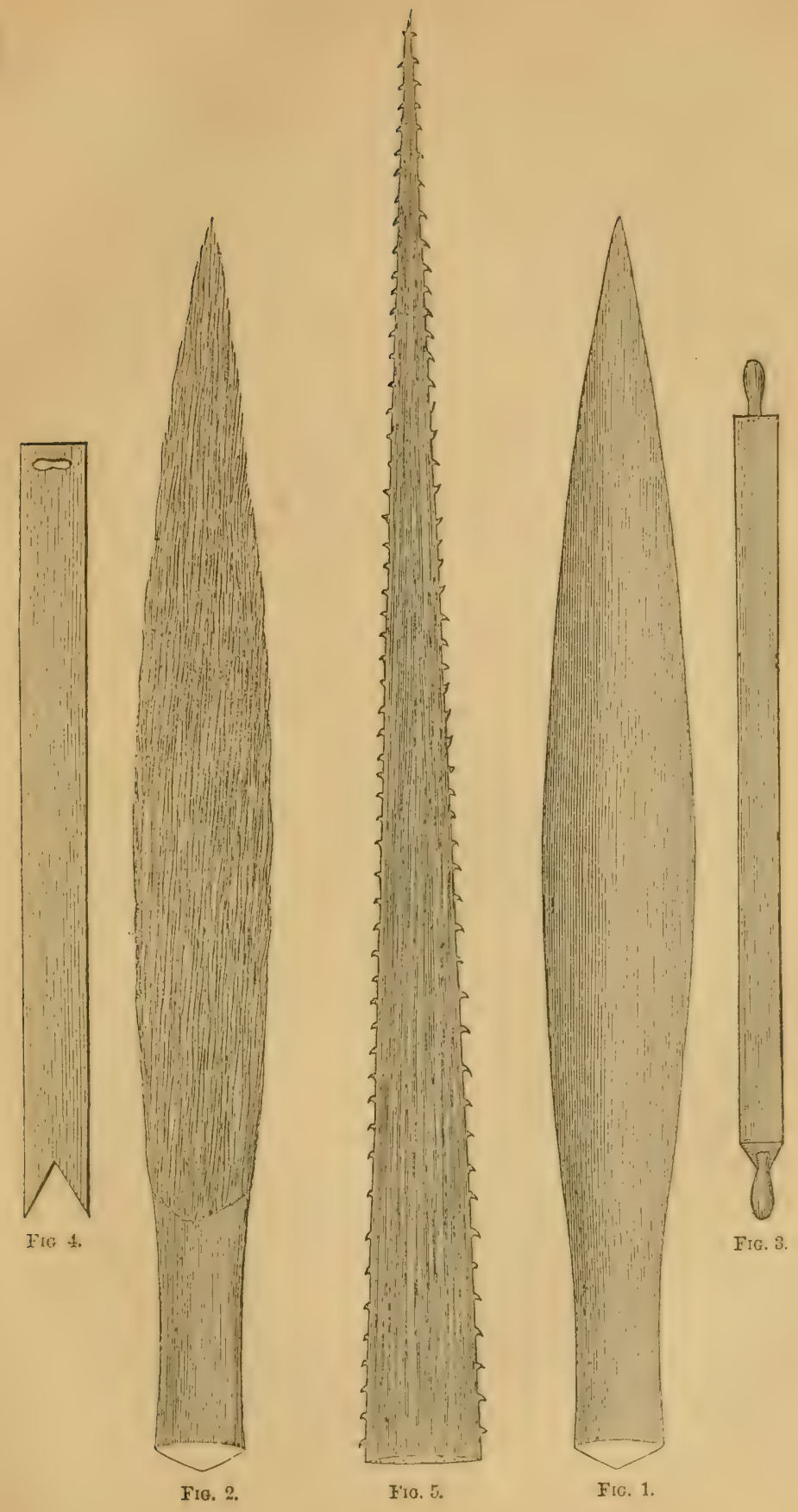




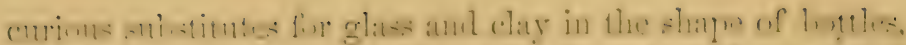

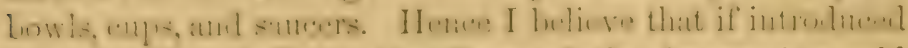

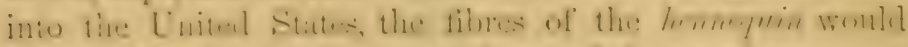

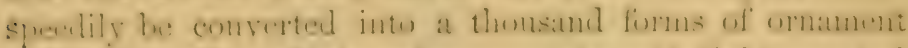

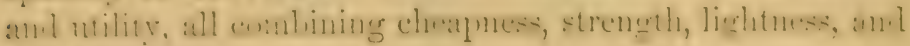
durability."

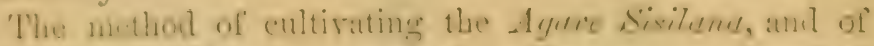

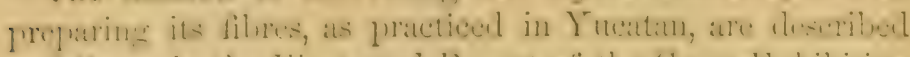

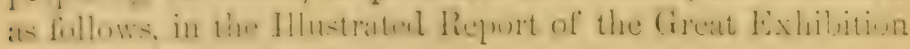
in New York, in 1853 :-

"The goung plants are plaked abont twelve fort apart, a

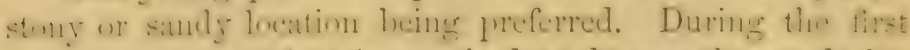

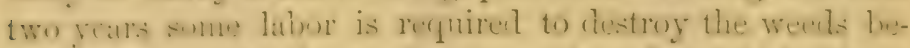
tween thene. 'The shouts when transplanted slumlel be alment three fiot high, ambl are realy to gichl two geatrs alterwarts. The thire yom the cutting of the lower leaves is commencel,

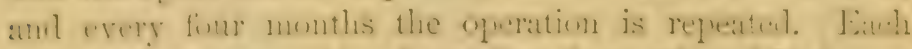

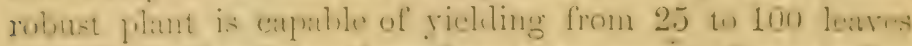
anmully, and will latet from live to ten years. Surenty-live orclinary leaves are estimated to yield seven and a half

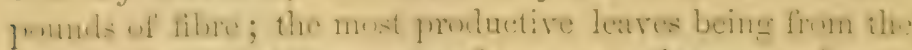
fondh cotting. At intervals of two years, shoots are thrown

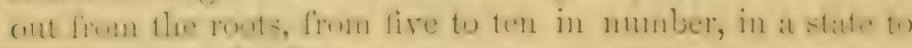

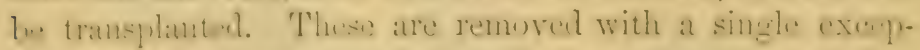
tims, to form mew platutations, ant the parent plant is alk

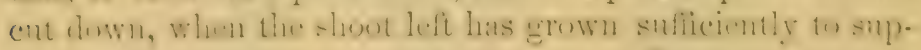
ply its place. If the parent plant be suffered to grow, it

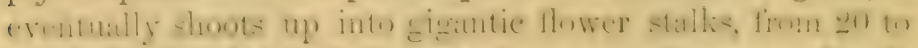

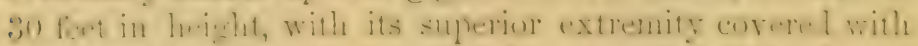

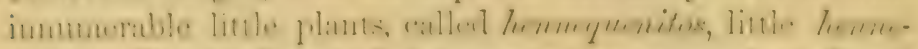

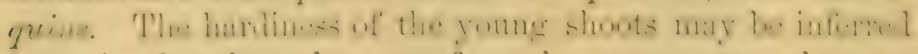
from the fact that when cut from the parent stem, they are exposed to the sun for fifteen or twenty days, to 'cicuterise their wounds' as a necessary preparation for replanting. "The simplicity of their cultivation,' says a writer on this

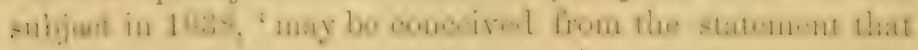
there is not a lioc, nor a spade, nor a harrow, nor a plough, employed in the agrieulture of all Yucatam.'

"Thie instruments and' methods used by the matives of 
Yucatan for extracting the fibres from the leaves, are of the rulest description. A triangular strip of hard wond, with sharp elge's from eight to twelve inches long, and from one to three inches thick, is with them an equivalent to the shaving-knife of the curricrs, by which they scrape away from each side of the leaf, on a board resting against the brenst, the cuticle or pulpy substance that covers the fibres. Another mode of accomplishing the same object is, by pressing the sharp, semi-lumar extremity of a long flat stick against any fixed surface upon a narrow longitulinal strip of the leaf, which is then drawn through by the memployed hand. The length, weight, strength, and other qualities of the fibres, as well as the labor of separating them, vary with the magnitude, age, and position of the leaves. The fibres, after being freed from the investing pulpy matter, are washed and chied in the sun, which thus completes the labor of preparation, and the Sisal hemp is then ready for market.

"One great difficulty in Yucatan, has been the want of a proper machine for suitably cleaning out the fibres of the Agave from their enveloping tissues; the rude process followed by the natives being too slow and expensive. An Inclian with his sharp stick only, and indolent habits, will generally clean from four to eight lbs. per diem. A few years since a machine was invented in Massachusetts, for cleaning the fibres, and sent out to Merida, by a Boston firm, having large commercial clealing with that city. The machine is understood to have worked well, but the regetable acid generated by the fermentation of the expresect juice of the leaves, corroderl the metallic parts of the machine it was brought in contact with, to such an cxtent as to renter them useless. The plan had consequently to be abanclonecl. Within the past year (1852), a chemical process has been discovered, which dissolves the green, fleshy part of the leaves, which the fibres remain intact, and after watshing are ready for use."

Dr. Perrine, an enthusiast in the matter of tropical fibreproducing plants, suceseded in 1535, in introducing into Floricla, the Algaee Sisilume, as also the Pulyue plint, or 


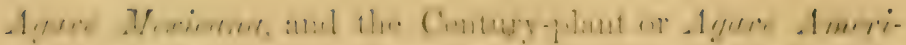
cence. Aceording to a statement from Mr. W. C. Dennis,

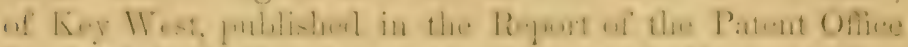

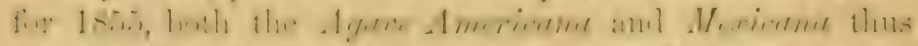

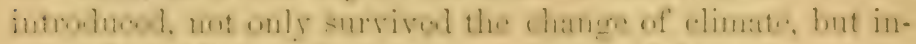

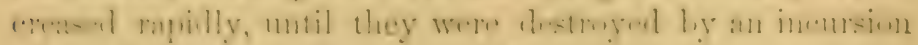
of the Suminole Indians, in 18t6. Of the three rarieties,

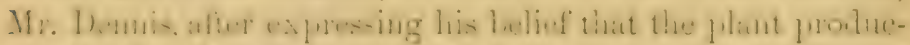

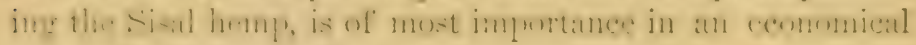
point of view, proceeds :

"This gigantiv flant helights in drient, roxky lame con-

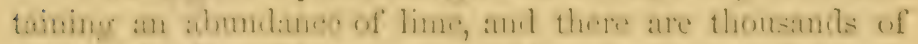

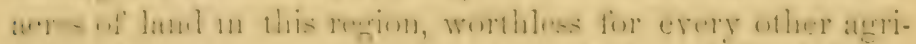

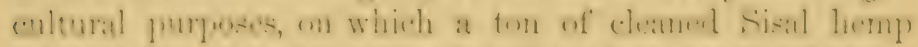

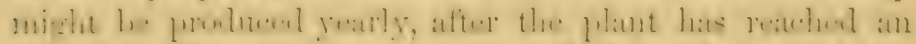
are to allww of entuing ofl its lower leaves, which would le: in from three to five years nccording to circumstances.

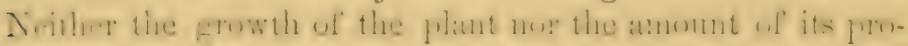
duct here, is any longer an experiment. Nor is there any lonere a cinclit as regarils the ralue of the tilue, a munlwer of tons of it having been collected and sent to market,

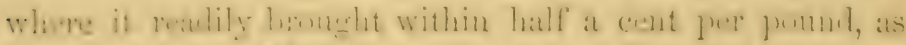

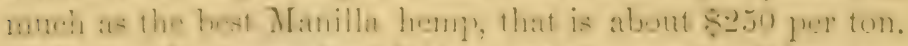

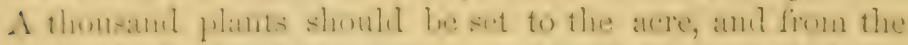
whlant shoots which sprine 11 , it will be seen that thes rand land will not repuire replanting. After the glant is of sullicient growth, the lower leaves are ent ond, at proper times, leaving enough on top to keep it healthy. 'I'hese

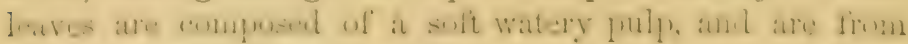
two to six fect long, from four to six inches wille in the

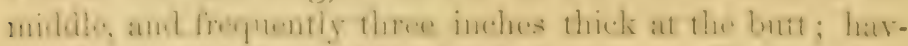
ine the general shape of the heal of a lane. There contain

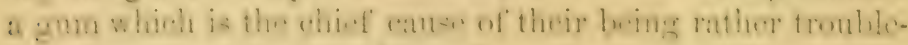
some in separating the fibres from the pulp. Neither the

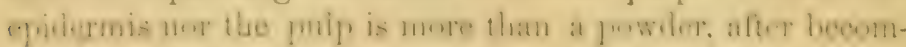
ing ilry, if the gum be entirely crushed or washed out. 'This is a most important fict, in relation to the manner to be adopted to cleanse the fibres from the pulp. As these

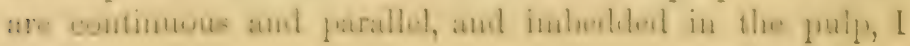


fecl certain that a system of passing the leaves through a series of henvy iron rollers, firmly set, something like those of a sugar mill, and throwing water on the crushed leaves, in jets or otherwise, in sufficient quantitics to wash out the gum, (which is perfectly soluble in water) will thoroughly clean the fibres without loss, so that when they become dry, and have been beaten to get out the dust, they will be fit for market. It cuny rate, the riglit plun for sepurating the fitres has not yet been discovered, althongh there has been cnough done in it to show that they can be got out at " profit. IIere, the people either preserve the primitive process which is practiced in Yucatan, of beating and scraping the leaves, or, after crushing them between a pair of rollers, steeping them in an alkaline solution for a few clays, and then hackling them. But both scripjing and combing destroys too many of the fibres by breaking them, which would not be done by a system of rolling and washing out the gum. In Yucatan, they sometimes ferment the beaten leaves in water or mud; but this stains and weakens the fibres so as to reduce their value, I believe, more than half. Even steeping the crushed leaves in an alkaline pickle, although it may not much weaken the fibres, as the juice of the leaves is acid, nevertheless destroys the silky gloss which they possess when got out of the fresh leaves, by the aid of pure water alone, besides increasing the cost of extraction. I have some fifty acres of the plint under cultivation, and am increasing the quantity as $I$ have opportunity."

In a subsequent communication to the Patent Office, published in its Report for 1856, Mr. Dennis gives some additional information concerning the cultivation of the Agave Sisilana in Florida, as follows:

"Mr. Ifermonds, of Indian River (Florida), informs me that the Sisal hemp grows well there, and has continued to thrive well for four years. IIe thinks that my estimate of a ton of fibre per acre is too low. The experiments which I have made cluring the past year, in getting out a number of tons of this fibre, prove that all the vesieles of the leaves are ruptured by crushing or rolling; and that the pu'p or gum can easily be washed out by either salt water or 


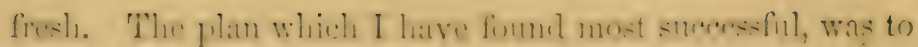

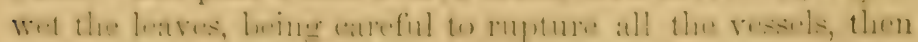

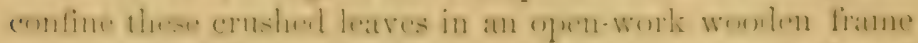
or twex, which I placed in streht at manner that the tide foroed the seat-watter throngh them both at the (-ib) and flow. In this manner the mun and gulp were sin far watelum ont, in from three to six dats lacemerlinge to the temperature of the air an I water), that by beating the fibres a linte, they were fit for market.

"Mr. Hermonts mentions, as at testerl fict, that steeping the

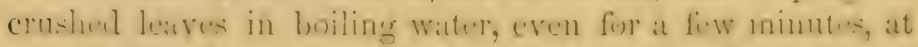
once disenlyel the gun and cleaned the fithe. This remlers it almost eertain that where a steannengine is nsed to purpel rollers amb erush the latses, the wiste stean can he remlerwl

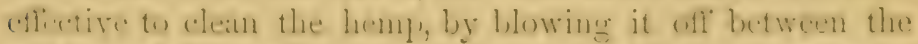

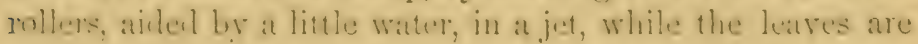
passing through." -1 mistalic. See Ante, p. 13.

The anomit of , Yival lemp imported inter the Linted states

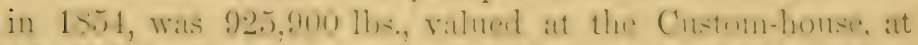

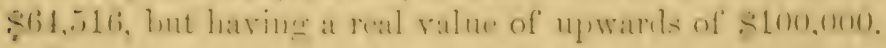

There is a species of Agave which is akin to the Sisilana,

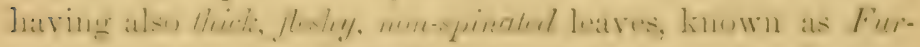
crea giganta. See Plate II. A variety of it, the Furcrea

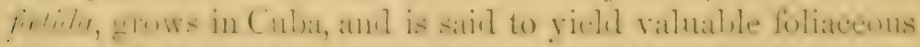

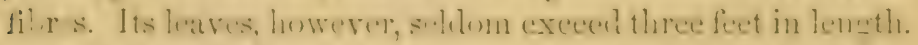

2. Agare Alexicuna, or Mfaguey, sometimes called Pulque

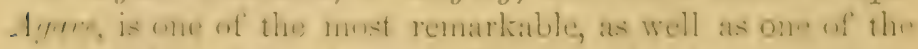
most useful of the Agures. From its developing stalk it

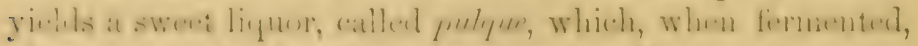
gives an intoxicating irink, nsent by the Mrexicans in flates of beer, wine, and cider. Its leaves also furnish a good

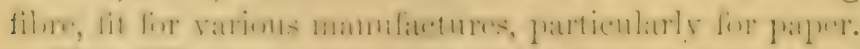

Plute III. shows the plant when the developing central stalls is ent asay and sony. ont, forming a natural reser-

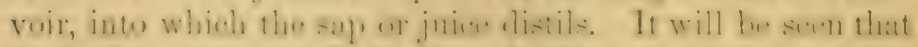

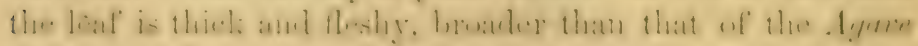

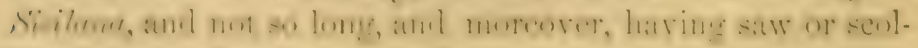
loped sharp edges.

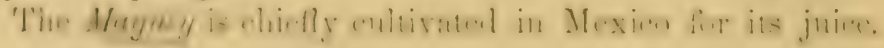


The plants are set in rows, about five feet apart. When the lecmpe, or eentral stem, which often attains the height of furty or fifty fuet, is on the point of efflorescence, it is cut out, and a hollow seooped for receiving the sap. This keeps ruming for two or three months, the reservoir being emptied three or four times a day. The yield from a vigorous plant is about four hundred cubic English inches per day, or, for the period of yicld, from forty to seventy thousand cubic inches, or from two to three liundred gallons! This enormous product is all the more remarkable from the fact that the $M$ a gney plantations are generally in arid grounds, and frequently on ledges of rocks scarcely covered with vegetable earth. The plant has firm and vigorous leaves, and is neither affected by drought, wet, hail, nor by the excessive cold which prerails in the higher Cordilleras of Mexico. It perishes after efllorescence, but an infinity of shoots then spring from the decitying roots. No known plant multiplies with greater facility.

The fibre of the ifaguey is coarser than that of the A. Sisilune, but nevertheless of great utility, and extensively used. The ancient Mexicans painted their hieroglyphical records and ritual calculars on paper made from the leaves of this plant, macerated in water, and the fibres deposited in layers like those of the Egyptian cyperus (papyrus) and the mulberry of the South Sea islands. And in modern times the fibres are used for a corresponding purpose.

Indeed, the paper made from the Murguey is so much esteemerl for its toughness and durability, over that made in the United States and Europe, that in 1830 a law was enacted by the Mexican Congress, requiring that no other lind of paper should be used in recorting the laws, or in the exeeution of legal documents.

3. Agare - Lmericena.-This plant, which has been naturalized in the south of Europe and Algeria, is often confounded with the Ireyney or Agute Sisilume. Its flowering or central stem, when the plant is vigorous, rises to the height of 40 fect or upwarls, and throws out branches on every site, like those of a candelibrum, so as to form a kind of lyramid, each branch supporting a cluster of greenish red fluwers. 'These 


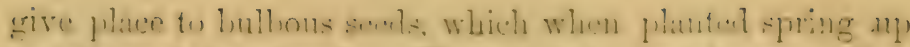
raphly and lnsurianty. The original plant luserer dirs.

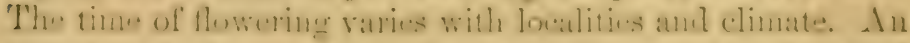

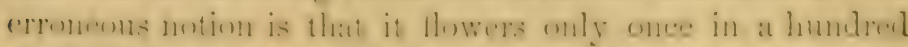

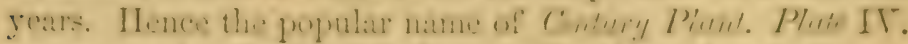

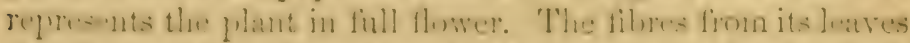

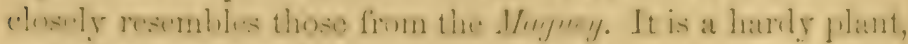
and often (a) wers rocky, latren sunimences, where every other kind of vegetation fails to take root.*

There are eight parder mills in Mexicu, which manufacture from eotten and the pritu. 'Their proiluet, however, is not (runal to the consumption. Mr. lirantz Mayer, in lis work

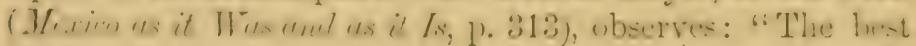

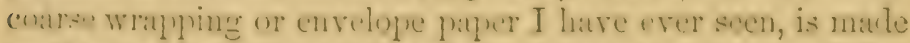

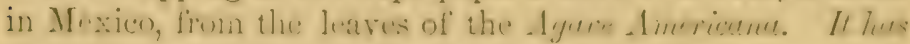
almost the toughness and tenacity of iron."

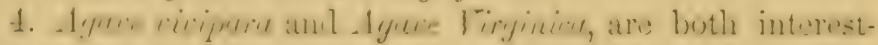
ing as being indigenons in the Cexital States from Vir-

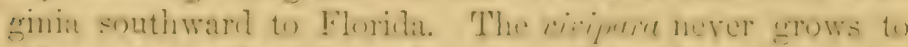

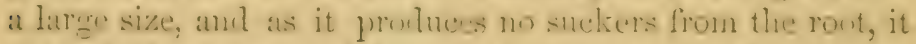

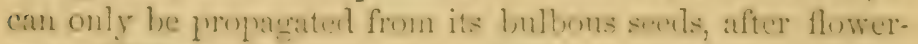
ing. Willian Baram, the colebrated traveler-naturalist, saw this vatriety, in his botancel tour through Forida in 1731, near the Mosquito river. His words are:

"I continued along the beach for a quarter of mile, and came up to a forest of the -1 fuec vieijuru. I term it a forrest,

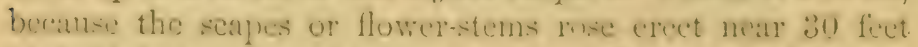

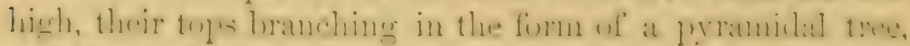

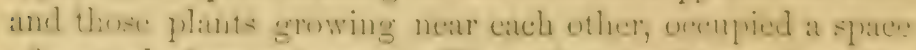

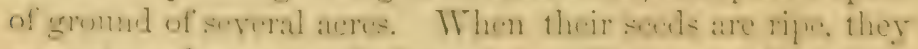
regetate and grow on the branches until the stend lies, when

" Mr. Stephens, iu his "Incidents of Travel in Central Amerien," describ.

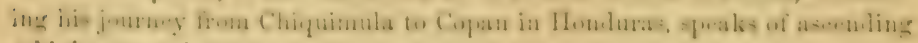
a high mountain:

"The ascent was toilsome, but the top was open, and so covered with that beatiful plant (Agave Americana, that we called it the Mountain of Aloes. Some were just peeping out of the ground, others were 20 or 30 feet high, and eome gigantic stalks were dend; flowers which would have kindled rapture in the breast of benuty had lilooned nud died on the desolate mountnin, unseen except by the passing Indian."-Vol, i., p. 90. 
the young plants fall to the ground, take root, and fix themselves in the sand."

Plute V, represents the Agave Virginice, which resembles the rivipure so closely as to be distingnished with difficulty. Its leaves are numerous, of paler color, and its stems are not so high, nor do they branch in the same manner.

Both varictios, it is fair to presume, produce useful fibres; but I am not aware that fibres have been extracted cxcept from the Agare vivipara, specimens of which, of admirable quality, were shown in the great Exhibition of 1851.

\section{II-Bronielia or Pine-Apple Family.}

The plants of this fimily are all incligenous to the continent and islands of A merica, and many of them yield fibres of excellent quality. One variety, that producing the delicious fruit known as the pine-apple, (- Lncenesse satica) has been introduced into the East Indies, where its fibres have been extensively used in the manuficture of the delieate fibric called piña (pronounced pinuya), as also for cordige, cte. The piña fabric, more delicate in texture than any other known of the vegetable lingdom, is woven from the untwisted fibres of the pinc-apple leaf, after they have been reduced to the greatest fineness. In order to produce a continuous threal, the selecterl fibres are glued together at their ends, forming an unbroken line, by which means the eren character of the fabric is produced. In the great exhibition of 1851, in Lonton, beantiful pine-apple threat was extribited from Java, Celebes, Singapore, Mathas, and other prarts of India. The fibres of the Brometir sylurstris, known in Mexico as istle or iatle, and in Central America as pitu or pinuctle, how. ever, are probably more valuable, in every sense, than those of anyother tropical pliant, and it wonld seem may be produced more readily than those of Agave Sisilana.

1. Binmelia sylecstris, or wild pineapple, the istle of M[exico, but known as pila and prumelle in Central America and Pannma, and in the TVest Indies as Brometiue pringuin or pereguin, can hardly be said to rank second to the henne- 


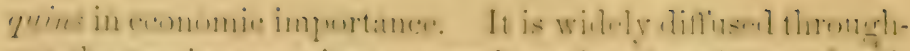

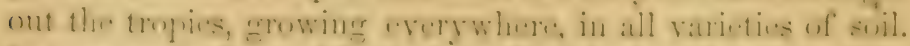

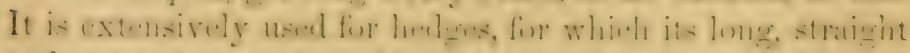
and sping leaves almirably allyt it, and may be coltivatel

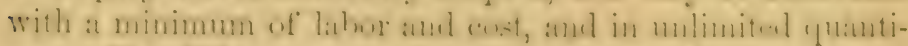
ties. Phe VI. mpresents this flant, with its flumering stron

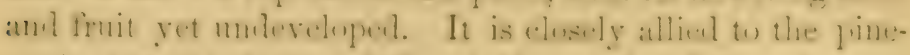

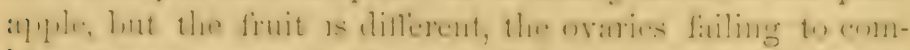
lim in one mats, as in the wate of the prine-alple, the formattion of which they well illustrate.

The leaves are five to eight fict long, from one amol a half to thren incleses wile, thin, and linem with a fine, tengh fibre.

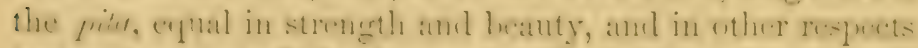

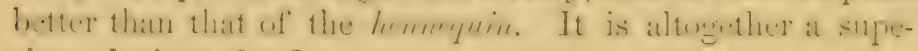
rior substitute for flax.

This plant is selfproplatating and left to isede in an open tich, will sum cuver the grmmul. In Central Ameriea, lut farticularly in Nicaragua, it is so abmolant in the forests ats to be a seriuns obstrution to the prosige of math or beast. Fig. 5, page 29, represents a leaf of this plant,

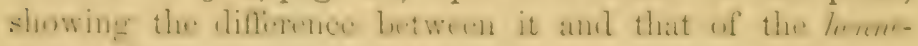
quin. It is largely cultivated in the district of Coatzaconters in Mexion, where, accorling to a report mate to the

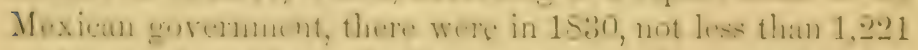

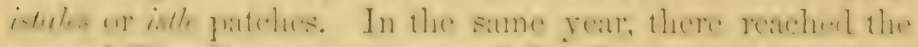

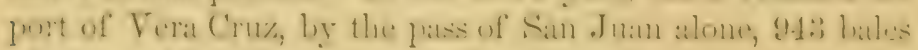
of fibre, of $200 \mathrm{lbs}$. each, equal to $185,600 \mathrm{lbs}$.

Major Tarnarh, I. . . ... in his repurt on the lsthmms of

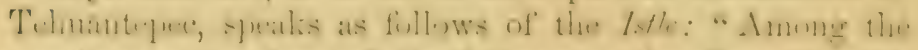

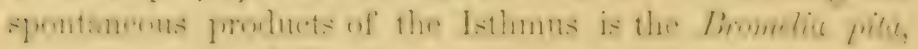
or iatle, which differs in some respects from the Ayave Americana of Europe, the pulque manuey of Mexico, and

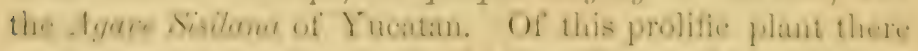
are munemos rariedies, all girling libres which sary in

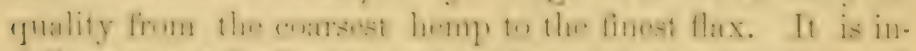

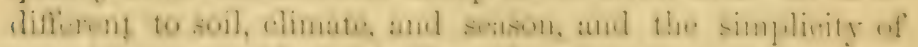
its coltivation, and the facility of extrating and preparine its products, renders it of universal use. lirom it is fabri-

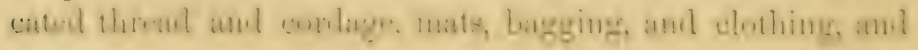


the hammocks in which the natives are born, repose, and die. The fibres of the pita are sometimes employed in the manuficture of paper; its juice is used as caustic for wounds, and its thorns serve the Indians for needles and pins. The place generally selected for its cultivation, is a thick forest, from which the small undergrowth is removel by cutting and burning. The roots of the old plants are then set out at a distance of from five to six feet apart, and at the end of a year the leaves are cut and 'rasped.' When the ixtle is young its fibres are fine and white, but as it increases in age, they become longer and coarser. In this manner it is easy to select the quality of fibre required. In a wild state its thorns are very numerous, but by cultivation they are dim. inished both in size and number, and in many instances there are none at all. Even with the imperfect instruments used in cleaning the leaves, four and five pounds of fibre per day is only "fuir average for the lubor of a man." - Isthmus of Tehuantepec, p. 185.

In the year 1857 (Jan. 11), Chief Justice 'Temple, of Belize, or British Honduras, read a paper before the Royal Society of Arts of London, on the resources of that country, which, as is well known, forms part of Central America. Amongst other objects of interest, he exhibited a quantity of the fibre of the plant under notice, as well of the Alyace Sisitana. Of the former, or Brometia sylvestris, he said: "The plant called Bromelice fritu, istle by the Mexicans, and silli-grass by the Creoles of British Honduras, grows spontaneously in the greatest abundance. The leave's are of a soft, dark green, from five to thirteen feet long, and from a inch and a half to four inches wide. Along the euge of the leaf, about six inches apart, are short, sharp, curred thorns. When the plant is cultivated, these graclually disappear. The fibre which the leaf contains is unquestionably of a very superior lescription, and I lave no clunbt could be used in every species of textile fabric. I have been informed by leading manuficturers that this fibre is equal to the best China grass, superior to the New Zealand flax, and capable of being mannfactured into the finest firbries."-Toumul of the Roygel Socity of -1,k, To\%. T., p. 125. 


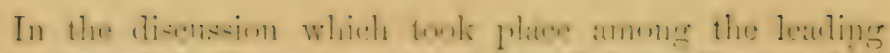

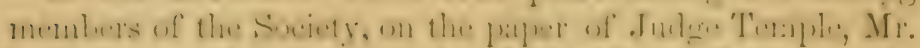

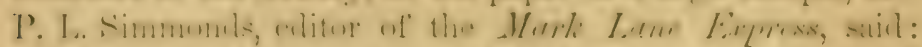

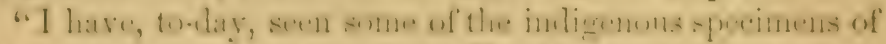

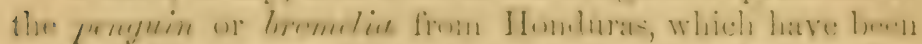

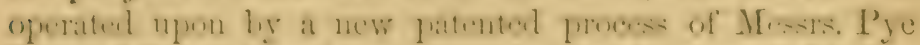

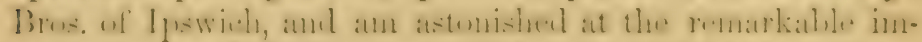

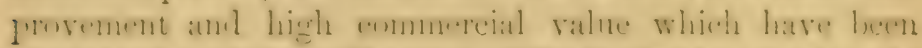

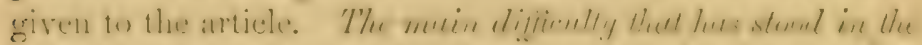

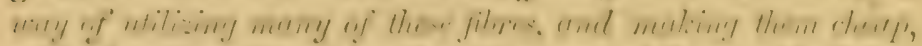

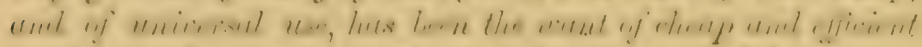

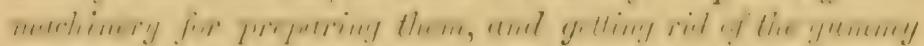
and ather mallers which surround them, without injury to the fibres. Such machinery is a desideratum of the ayje."

Mr. Pye renarlat that, "On the anthority of pratival

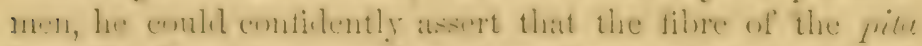
linemelie, from its stremeth and quality, might be remlered fit, by the hackling process, for the finest fibrics."

Mr. J. B. Sharp said that "He could confirm all that

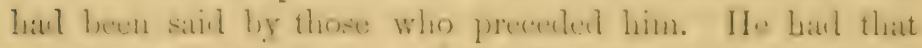
moming submitted sme of the fibres to a chee miomscoplicat? exandintion, and hat asertaines that each fibre

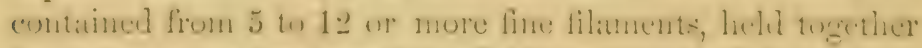

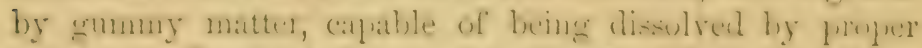
procenses. Some of the specimms before them hial lasen

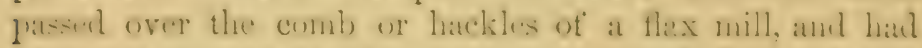

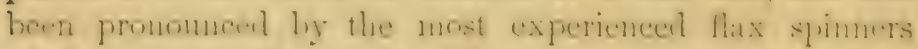

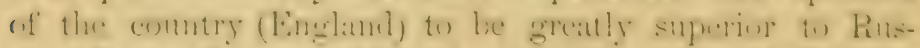

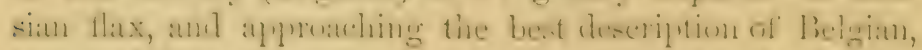

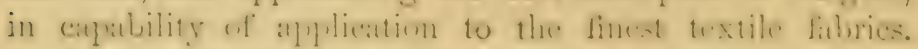
* * $\Lambda$ material point to be considered was the machinery

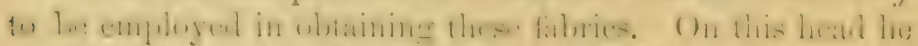

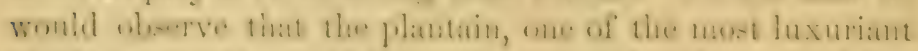

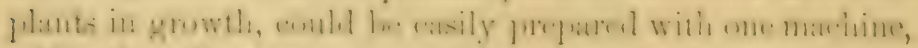

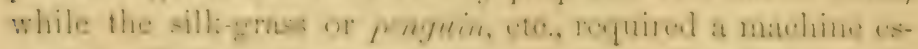
sentially. diflerent in construction. * * 'The leaf of the sillegraes enes of of two difierent strmetures; the uppor

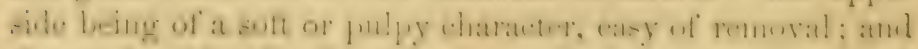
the unler side of a harier or more lignoous chataster, and 
more clificult to separate-these two external boclies holding the fibre between them. The preparation of the fibre, however, was a question of mere mechanical arrangement. * * Me had no hesitation in saying that the three Iritish colonies of Jamaica, IIonduras and Guiana were capalsle of furnishing fibres from the plants in question to the value of $\$ 15,000,000$ per annum."

There is another variety of this plant, the B. Raratis, which is hardly to be distinguished from the 13. penguin or sylvestris. It is found chiefly in the dark woods, and has been supposed by some to be the true $R$. sylvestris, changed only by the conditions of its growth. It is probably equally valuable for its fibres. See Plate VII.

III.-Bromelia ananas, or edible pinc-apple, which also affords fine foliaceous fibres of practical utility, has leaves about three fect long by an inch and a half to two inches wide, strongly edged with spines. These may all be worked when the fruit is eut, the plant being perpetuated by shoots from its base. Left to itself, these shoots will gradually cover the entire ground. The shortness of its leaves, however, render this plant inferior in value to its wild brother, the Bromelia syluestris or penguin. The plant, which is a native of America, has been introduced in the East Indies, where its fibre is cxtensively used in manufacturing the delicate fabric known to commeree as piñu. See Plate VIII.

\section{III.-Musa or Banata Familu.}

The various members of this family rank only second to the Agaves and Bromelias in the quantity and value of their fibres. Several varieties are cultivated for food, yielding a delicious and nourishing fruit, and in such abundance that II umbolit estimates the product of a single acre as equal to the average proluct of 133 acres of wheat, and $4 t$ acres of potatoes. An interesting, and for the purposes which we have in view, a most important finct, is that the tree or plant, whether plantain or banana, is almost universally cut down when the fruit is gathered. With proper machinery for extracting the fibre, the many millions of plants thus left to 
rot, conlit be converted into articles of firet utility for mankind, such as cordage, cloth, paper, etc.*

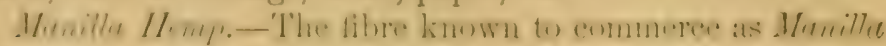
II me is extrated from a ratrety of the Banana, the mese

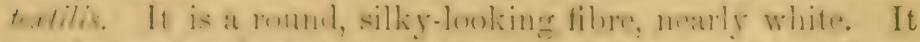

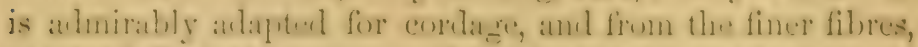
whtainen from the pretioles of the leaves, are manle many of the deliente and celebrated muslins of India.

The stems of all the plants of this omlep or fanily are mate up of the uniterl petioles of the leaves. 'They comtain such a renatriathe abmulanee? of spiral vessels that they ean le pulled ont hy handfuls, and are soll for timler. Each spiral resed antains sis or seren filues, which when separated constitute the Manilla Hemp.

The vilue of Mantlia ILomp, in the English marlet, is about ses per ton more than the best linssian hemp. t

- In the official repert of the great Exhihition in J.mulun (18.51) it is sater

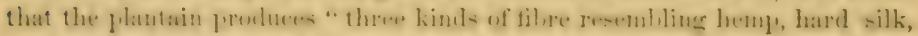
and cotton, capable of being worked into cordage, fustians, lawns, gauze, blonde-lace, and candle-wicks."

t In the consular returns for 1854 , published by order of the United States Government, (vol. iv., p. 200), under the head of "Manilla," it is said of the Manilla shipping.

"The standing rigging is of European rope, and the running rigging of rope made from the fibres of the plantain tree, called in the United States Manilla hemp, and in this market $A b a c a$; or from Maquey, a fibre identical 1 believe with that known in the United States ns Sisal hemp. Manilla cord. age is usually sold at an ndvance of st per picul on the cost of hemp, or from 7 to 9 cents per lb. The Iraguey rope is much cheaper, but inferior, owing to the hemp being imperfectly cleaned. * * The hemp which is

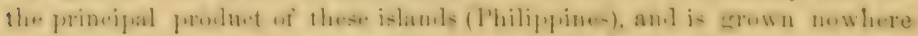
else, with advantnge, is in such fuvor in the United States that to this date the demand has in no year being fully supplied. To this article is due the increased eommeree with the United States. * * The plantnin tree from which the hemp is obtained, is cultivated with the greatest facilsty, but the opcration of separating and cleaning the filtes is rery laborious. A machine has recently been invented by an Amerienn engineer in Janilla, which it is to be hoped may be neeful in snving labor and inereasing the produetion.

"The export of Manilla hemp, to the United States nnd Grent Britain for 1852 was $4,018,000$ lbs, or in value $\$ 5,350,000$. To show the rapidity with the demand for this product hns increased, it is only necessary to men.

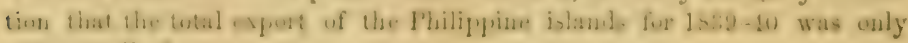
$5,870,000$ Jus," 
Plate IX. cxhibits the appearance and mode of growth of the Iluse rosuced or red binnana, and will serve to illustrate the entire class. The lamina, composing the stalk, are from 10 to $1 \pm$ feet long, by from 4 to 6 inches broad, and are used for many purposes, such as matting and wrapping, in their natural state, without any other preparation than pressing and drying.

Among the articies sent from British Guiana to the Crystal Palace cxhibition in New York, in 1853, were a large variety of the products of the plantain and banana, consisting as well of their prepared fruit, as of the fibres, and cloth, cordage, and paper made from it. I extract from a report on the exhibition, published in Demerara, a number of interesting paragraphs on these plants and their products, all of which concede that proper inachinery to extract the fibre, is alone requisite, in order to make it an article of prime commercial and industrial value.

"Many indigenous (and this is true of all tropical American countries, as well as of Guiana,) contain fibre which might be turned to profitable account, as a substitute for hemp. Cordage of every thickness, from the finest line to the stoutest cable has been manufactured from them, and found to endure the severest test to which it could be subjected. Paper Las also been made from the fibre of the plantain stens which are now thrown aside to rot on the ground. One sort for writing, another quality resembling parchment, and a coarse strong article for wrapping goods, lave been obtained in the very infancy of the manuficture, and there is every probability that superior paper of all descriptions, may be produced, as improvements in the process are effected. The plantain is of rapid growth, and exceedingly prolific, and demands little attention to its cultiration. Its fruit is the bread of the tropics."-(Introduction of Report, p. iv.)

Plantain fibres from stems six to eight months old, and also from the stems after bearing fruit, were exhibited by A. D. Vander Gon Netscher, with the following statement:

"I have had an experience of ten years in the cultivation of from 400 to $t 80$ acres of plantains. On every acre from 700 to 800 stems are cut annually, either for the fruit, or 
after having leen hown dewn by high wints, discase on other reatons. If enlivater for fibre, I an of opinion that by entting then down every eight months, from 1400 to 1.rut gond stems enuld be harl at every cutting, or 4,500 in two years. The areratere weight of the plantain tree is bo llis. and after reprated trials I have fonmel that it will yiehl $2 \frac{1}{2} 115$. clean, and $1 \frac{1}{2}$ lls. of discolored and broken fibre, fit mily for enarse paper, per tree; this however, ly rery inporfent nachinery. The keeping up of a plantain estate costs about $\$ 30$ per acre annually." (Report, p. 3.)

Plantiin stems driet, from Inver Island, Dencrara River, were exhibited by Daniel Blair.

"The trees were passed through the iron rollers of a sugar mill and dried in the sum. The plantain is an annul, herbatcons tree, areraging alunt thirty inches in circunferenee and from 10 to 14 fert in height. It consists of alout 90 fer eent. of water, containing salts and tamnin in solution. All its solid parts are entatined in the specimens, consisting of thine aml connecting cellular tissue. The yidel in this

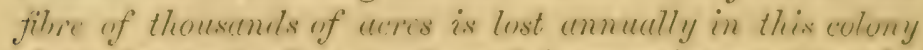

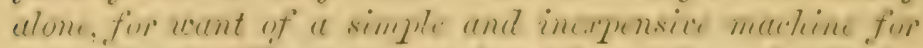

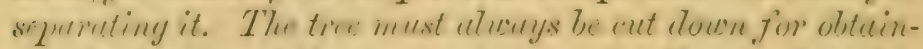
ing the fresit, and thes stem contrining the giture is allowed to

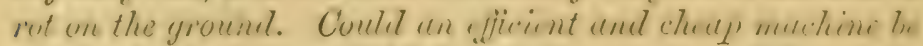

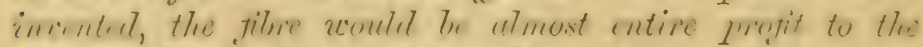
fuluter. The banana yields less fibre than the plantain tree, and its fibre is generally tinted." $(I b,$, p. 5.)

"Eight or nine months after the sueker has been plantenl, the hanana berins to form its clusters, aml the fruit may be Goutherel in the tenth month. When the stalle is cat, the frut of which has ripenet, a sprout is jut forth from the ront which arain hears fruit in three months. The whele? labor that is required for enltivating a plantation of banamas or flumtans, is to ent the stalles when the fruit is ripre, and brakk up the earth a little onee or twiee a year around the

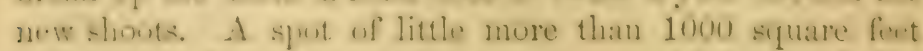

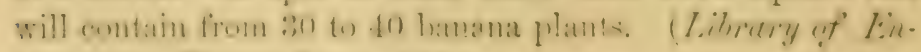
terlaining Ḱnowledge, p. 366.)

Althongh the stems of the ordinary plantain and baname 
produce fibres in no perecptible degrce different from those of the Mnesa textilis or abace of the Philippine Islands, yet the French government, many years ago, undertook the introcluetion of the latter into the Islands of Guadaloupe, and Martinique, where it was found to flourish as well as in its native soil, and where it has propagated itself to a large cxtent. (Annales Maritimes ct Coloniales du France, fol. vi., p. S6.) M. Perrouttel, Botinist of the French gorernment in Guadalompe, in the work just quoted, has given a very full account of the abaec of Manilla, and the mode of extracting its fibres, which, as equally applicable to the plantain and banana proper, I here translate.

"The abaca of the Philippines differs essentially from all the varieties of banana known. Its stem, which rises from a tuft of shoots, has a height of from 15 to 20 feet, of a dark green color, and very smooth on its surface. Its leaves are of the same color, long, and straight, with strongly marked nerves both parallel and transverse. The fruit is small, triangular, resembling abortive bananas, and scattered here and there near the extremity of the fruit-stem. It is full of black seects, almost round, similar to those of the gumbo. These seeds fructify rapidly after planting, and the young plants are strong and vigorous, attaining the dimensions already indicated within the short space of eight or nine montbs. The plant requires a rich and humid soil, and rejoices in thick forests, at the base of mountains, where it acquires, in a short time, an extraordinary development. I have never seen it in such perfection as on the humid, yet high grounds belonging to M. de Lacharriése (Guadaloupe), notwithstanding its entire abandonment to itself, in the milst of a jungle of other plants. Only two shoots were planted here, about seven years ago, yet now the whole valley is corered with them, so as to resemble a forest. This fitct proves sufficiently that the plant is robust and easily cultivater-indeed, that it can be propagated with a minimum of care, to the greatest needful extent.

"No doubt however, its regular cultivation would be bencficial in many respects, especially if the plants were liept at a reasonable distance apart, so as to permit their full 
development. In the Plilippines, the stems are cut diswn as near the ground as possible, at the moment they evince signs of Hewwering, that is to say about eight months after planting. The onter sheath or envelope is then strippen ofl, leaving the petinles that compose the stem proper. The stem is next split into two and afterwards into four parts, atter which the petioles or latyers are striplped ofl; working from the exterior. 'Thoee composing the rery interior or heart of the stem are thrown asile, as being lestitute of fibres of snflicient strength for economic purposes. 'The resorved filaments or slips are now pomblet with chuls of haml wood, first on one side and then on the other, mutil the transversal and cellular tissues, and porous and gummy matters are expellet. After this the filores are passel frequently through a eoarse hackle, and washed many times in clear, rumning water, until lerfectly free from all extraneons matters. They are then hung oser ropes or poles to dry in the shade.

"- Is the fibers are not all of the same size, those being finest which come from the slips nearest the heart of the stem, they are carefully sepanated by hatid; the coursest heing latel asile for cables, ropes, corrls, ete, accorling to their relative finenes, while the finest are reserved for the more delicate tissues.

"In sending them to Europe for sale, the fibres are parelien in bales of greater or less size. 'Those which are of fiftern fict in lengll or mpwark are folked back on themsel ves three or four times, aceorling to the length of the cates containing then: those of less length are follted two or three tines; after which the eases are hermetically closent, in orker to fre. tect their contents from humidity on board ship.

"This is the manner in which the alued of the I'hilip.

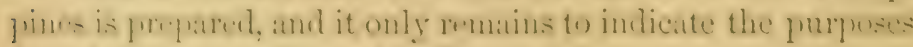
for which it may be used in France.

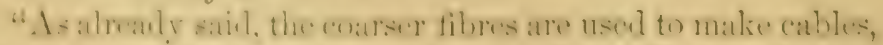

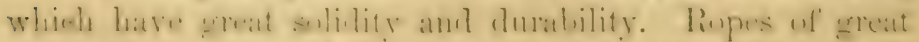

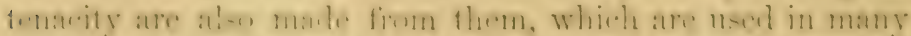

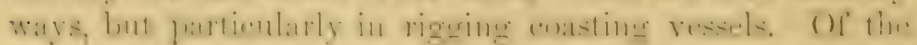

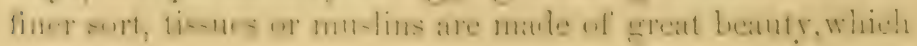


are very dear, even in Manilla. I had a number of shirts made from this muslin, which lasted me a very long time, and were cool and agreeable in the use. But it is especially in France that tissues of this material are best macle and of greatest beanty. They receive all colors with equal perfection. Vails, crapes, neckerehiefs, robes, and women's hats, all of great beauty and high cost, as well as of wonclerful durability, are among the manufactures from the abaca fibres. Besides these are marle various articles of men's wear, such as shirts, vests, pantaloons, etc.

"Ever since this precious fibre became known in France, our vessels have frequented Manilla, returning freighted in part with the article. The quantity imported, however, falls far short of the demands of the manufacturers, and its production certainly deserves the attention of all our southern colonies. Its cultivation, as we have seen, is easy, and, as regards cost, next to nothing, and there is no reason why it should not become an important article of commerce throughout tropical America."

MI. Jules Itier, special agent connected with a late French Mission to China, made a report to his government on the proluctions and resources of that empire, which is published in Tol. VIII. of the work already quoted. He states that the plantain shoots are set, in furrows six inches deep, and fourteen feet apart. The fibres are separated as above described, each plant yielding 42 ounces. An expert latorer can extract fifty pounds per day. M. Itier adds:

"The abeece cloth is almost transparent, somewhat rigid, light, and cool to the touch, and is used by the Togals for napkins, hanclierchiefs, shirts, etc., of various colors. The fibres are not spum or twisterl, but the threads are used in their natural state, being only tied together at their ends. They are next wound into balls, soaked for a day in hot water, dried in the sun, and are then ready to be woven."

The necessity for the introduction of some new, cheap, and abundant fibre as a substitute for cotton and linen, in the manufacture of pap. $\mathrm{r}$, is universally recognized. Tarious attempts hare been made to supply it from various nuaterials common to morthern latitudes, but without suceese. 
The bark of the willuw, limblen, amel even the common nectle,

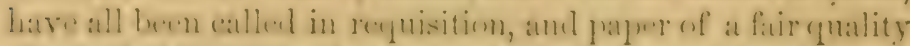

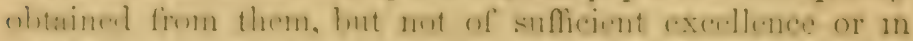
sufficiont quatitiy to smply any consinterable part of existing lemants. The sulject was loromeht up am rery filly investigater in response to a prize of $\$ 5,000$ allimed on Iwhall" of the "Ioniton 'Times," by Mesers. Smith d. Son,

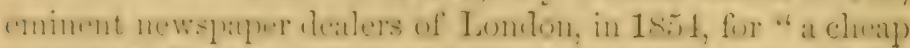
sulstitute for the cotton and linen material now used by louper makers," sulyject to the comlitions of being "practicilly mulimitenl in guimtity, and in cost ten per enont. lower than the materials now used." Paprer mate from a great variaty of substinces was offered in connetition for the prize, hut nome answerel all the comlitions aceompanying the offer. Paner from the fibre of the plantitin came nearest nexting the requirements, it being alnitted that the jmportunt conlition of quentity of fibre for its manuficture onula

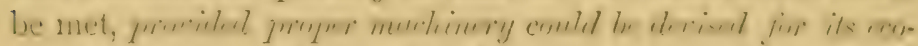
mamie cotimetim. 'The quality of the paper as regaris strength and finemess proved to be all that was reguired, and if prepared with skill, it was helieved that in color and in every other refect it would prove ecpual if not superior to the kinds of paper now in use.

\section{V.-THE PAIM FANITY.}

There are a number of varieties of this large ant useful class of trecs which proluce valualle filores, ant which only require froper mathinery to contribute latedy to commercial and manufacturing purposes.

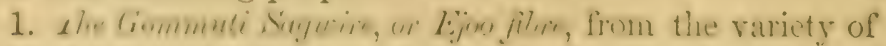

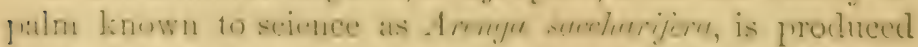
by the splitting or deray of the leaf-stallis. To the natives of the trepies, these naturally prepared libes are invalualle, supplying then with materials for consats, combleg, and a variety of economic purpuses. It is hest known as a pro. duet of the liast Inlies, but a similar artiche is alon fomm muler the tropice in America, where it is jumbeal from a

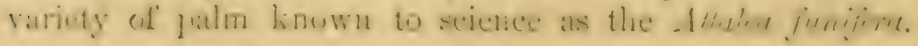


The tree producing the gommuti fibre, rises from twenty to thirty feet in height, and has a dense crown of leaves. (Plate $\mathrm{X}$.) The petioles are very stout, and it is at the base of these, completely embracing the trunk of the tree, where the horse-hair like matcrial which cö̈perates to render this palm so valuable, is found. Cheaper, more durable, and stronger than coir, it has the additional advantage of resisting moisture, for which reason it is highly valued for ropes, especially cables, from their not being liable to injury when stowed arvay below, wet with salt water. Underneatlı this naturally produced fibre, the Gommuti palm produces a soft, gossamer-like substance, called boru, used in place of oakum for caulking, etc.

To the natives of the East Indies and the Philippine Islands, this tree is invaluable. Its juice when reduced, produces sugar, and when fermented an intoxicating liquor. From 150 to 200 lbs. of sago may also be obtained from a single tree, which also furnishes from four to seven pounds of fibre.

2. Piassava, Monkey grass, or Para grass, and called by the natives chiquichiqui, is produced from a variety of palm (Attatec funifere) which abounds on the Amazon river and its tributaries, in very much the same manner as the Gommuti fibre from the Arenga palm. The tree is one of the most elegant of its family. Its stem rises from twenty to thirty feet, straight as an arrow. From the top of this springs a tuft of pimnated fronds or leaves, often mearly twenty feet in length. Before the decay of the petioles, the fibres become detached at the margins of their bases in large quantities, langing down ten or twelve feet in tufts, whence comes the name funiferc, rope-bearing. Nearly all the cordage used on the Amazon, is made from the piessura fibre, which is remarkably round, not vory pliable, and often about the thickness of the small green rush. Eight hundred tons were exported from Para in 1S51, to England, where it is used for maling brushes and brooms. The brushes of the street-sweeping machines of London are made from this fibre.

3. Coir or Cococ-nut Fibre, manufactured from the husk or 


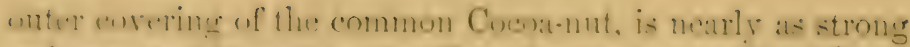

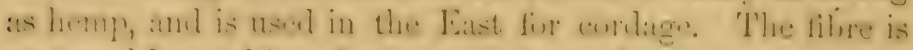

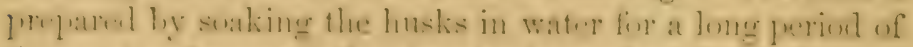
time, mot unfrexpenty fir six mombe, and until they hecome

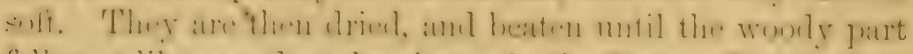

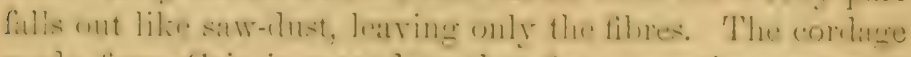

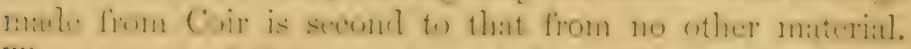

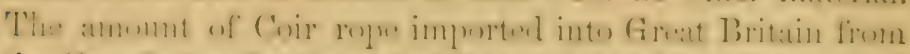

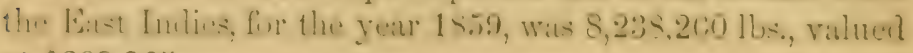
at $\$ 392,265$.

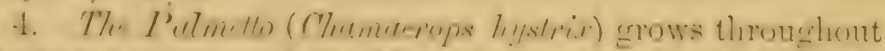
Coutral Amerian and the Trest Indies, leoth in high rocky Fromm, and on low, moist lamkls uear the seat but alprears in thrive lest in the fomer. It shoots by a simplestalli, and has maximnm lecight of tento fonteen feet. It is always fumished with leaves of the form of a fan, su-taimel hy slemter ecrm-

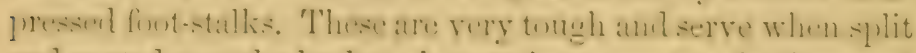

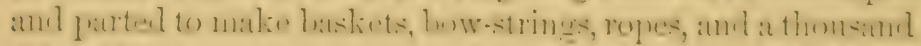

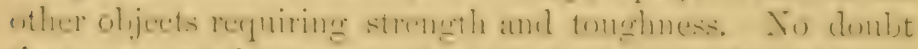
the proper mathinery wonld enable trepical resilents to for-

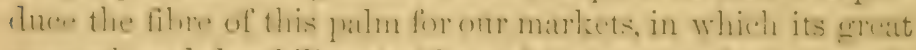

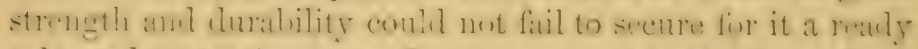
sule, and exteneive nise. Specinens sent to the Gireat Lome ton Exhabition of 1s.51, from the Bahamas, receivel "honorable mention."

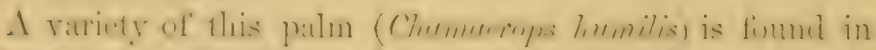
Wretern Asia, Northern Afriea, ant Sinthern Finme. The

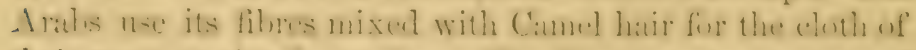

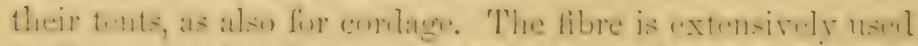
in France moler the name of "Afriem hatir," in the mantfacture of carpets. It is used also for sails, and for this lurpwas it is regartol as superior to spanish broom. It hats

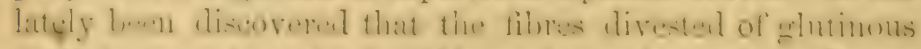
malter, we extromely divisible, and may be mate as fine as flitx ant into what is celled tlax cottenl. Sime 1854, they

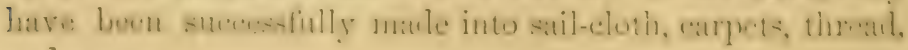
and paper.

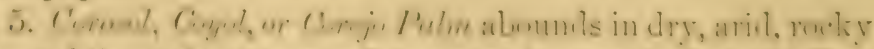

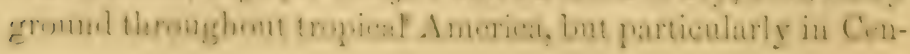


tral America and the interior of Cuba. It grows to the height of twenty feet, and the trunk is covered from bottom to top, ats are also its leaves, with long, narrow, sharp, and hard spines. It produees a large eluster of nuts with a hard shell, of the size of grape-shot, from the liernel of which is extracted an oil indistinguishal)le from that of the Cocoa-nut. The woody cxterior of the trunk covers a pulpy heart, saturated with juice of a fresh, agreeable flavor, which may be obtained by incision, called lino de coyjol. When fermented, it becomes intoxicating like the mulque of the magrey. In times of great drought, when vegetation is destroyed, this pulpous heart is often fed to cattle. The leaves of the coyol are lined with a long and excellent fibre, called in Cuba Pita de corojo, from which ropes, cords, ete., are manufactured. The fibres are equal to those of the henenein, from which they can hardly be distinguished.

6. The Cuthoon Pulin of the English, Coroso gallinazo, of the Spaniards, and the attalia colume of botanists, is one of the most luxuriant and prolific, as well as one of the most beautiful of the palms. It lines the coasts and watercourses of Central America, and sometimes occurs in vast purlis, completely covering the ground with its arching leaves, under which the traveller may pass perfectly protectal from the rays of the sun. Its trunk rises to the height of from thirty to forty feet, and its leaves are often from twentyfive to thirty fect in length. Their stems are lined with fibres, which no doubt could be extracted of the whole length of the leaf, by the use of proper machinery. I am not aware that it has ever been used except by the Indians; but if really available for manuficturers, the accessibility of the palns producing it, and their great abundance would make its extraction casy and profitable. This tree produces a nut similar to that of the coyjul pulm, which grows in clusters, a single tree bearing from 500 to 800 . The liernel yields an excellent oil, equal if not superior to that of the cocoa palm.

The Ticu Pulin of the marshy grounds of the Orinoco, and the Ite, (Iauritic flexuosa or Jlurriche Pulm) of Brazil, furnish abundant and excellent fibres, as well as food, drink, 


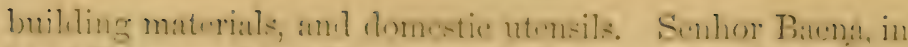
his "Chorographical Essay on the Provinee of Tara" in Bratzil, silys: "There are known twenty-three diflient palntrees, rach yichling fruit, fileres, conderye oil, an d even spirits."

In Inclia, the faltus producing fitures are also nunserons.

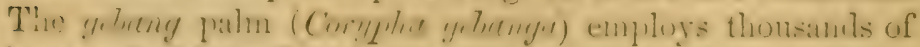
boys and girls in Java in weaving baskets and bags. Shirts, fishiner-nets, ete., are male from its fibus, and romes from its twisted lenf-stalks. It is one of the most nsedinl of the Indian rarieties of the palm. The Ceryoth wirks, which attains a height of forty feet and often grows to be a foot in dianeter, hats leaves from cighteen to twenty fert long, from which filores of great strength are extracterl. These are nsen] for brushes, broms, ropes, ete. The juice of the tree when

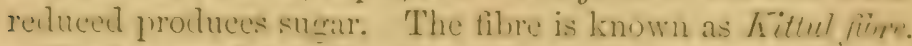

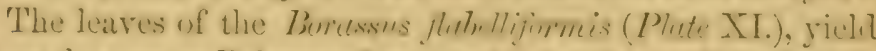
fibre, known as Palmyra fibre, ats do al=o those of the Brazilian Carnuba palm, Corypha cerifera.

Fibrous materials are also obtained from the Segus filuris, a Malay palm, and in Afleghnistan ropes and cords are made from the fibres of the Maizurrye Palm.

\section{VI.-The Pandanus or Sorew-Pine Family.}

Plants of this order are extremely abunclant on the coral islands of the South P'acific and the Indian Archipulagu, :und alsis on the Isle of France. In America they are rare. In Intia they are extensively used for hediges. The Pandams grows naturally on arid, sandy; or rocky snils, and from the "ly"re prat of the stems shoots out nimerous arial routs, which hurying themselyes in the suil, surve as stays or braces to prevent the plant from being uprooted by the wincl. The leaves of all these spories are thmons, and in the Sonth l'acilic furnish almost the only material for chothing, matts, wrelace, bageine, rete. The filues are white, suooth and lus. truns. All the surecies are easily proplatert, and their natural dublitut appears to be thote sterih, arid districts of the trupies which are unfit for any uther useful regetation. See Plate XII. 


\title{
CHAPTER V.
}

\author{
EXOGENOUS PLANTS.*
}

Of the exogenous plants producing fibres, the Urtica or Nettle, the Malva or Mallow, and the Lilia or Lime Tree familics are most important. Some varieties of the Leguminosae and Asclepia or Nilkwood families also produce fibres of good quality.

\section{The Urtica or Nemtle Family.}

"This family, in all its subdivisions, produces plants abounding in excellent fibre. One division, the Hemp sub-

* Dr. Schaeffer has made some judicious observations on the extraction of fibres from this grand class of plants, and also on the practical cultivation of the plants themselves, which are worthy of a place in this connection:

"Many plants of this great dirision of the regetable kingdom are herbaceousthat is, grow with but little strength to the stem for one year, and then die down to the ground, or altogether. Even perennial plants of warmer climates may, in the milder regions of the temperate zones, become annuals. In the case of true annuals, there is no need for any great hardening of the woody tissues of the stem, as the sole end to be attained is a sufficient support for the plant until it flowers and the seed ripens. Herbaceous stems, which die down to the ground each year, are evidently designed for a similar, restricted end. In the case of perennials, which, in other climates might become, at length, woody shrubs, a single year's growth is not enough to allow of much induration of the wood cells; and heuce they approach nearly to the condition of true annuals, although the tendency to produce firm wood is constantly shown. If, under either of these three heads, a plant is found which furnishes a long and useful bast, a common and well. known mode of treatment can be cconomically employed for the separation of the tibre. The plant is exposed to the action of the air and moisture, with more or less of fermentation, until the different tissues become separated, and even until the different cells are loosened in their adhesion, by which the harder and shorter woody fibres are broken, and in part remored, while the pliability of the bast allows it to pass through the treatment without injury. At the same time, the short and more tender cells are also removel, the latter stages of the process difiering for diflerent plants, all contributing to the complete separation of the remains of the adherent and useless types.

"Two things, then, must concur to make a useful fibrous plant, for not only must the bast be long, pliaut, and in bundles of the proper size, but the wood which is 
family, contains not ouly the well lanowa hemp it:elf, lint

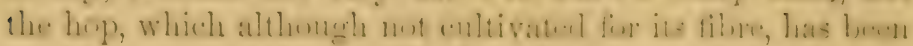

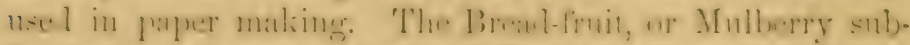

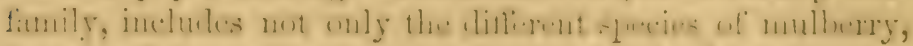

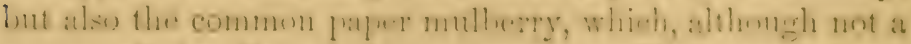
native of the Luitul states, grows raulily every where.

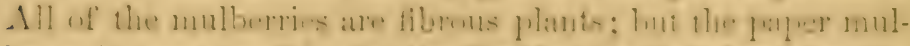

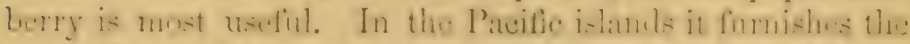

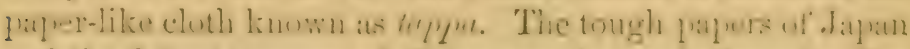
and the delicate papress of China are aleo mate from it. For fihrous purposes the platnt shoulh lne cultivatual so at wo give long and slender shonts, atter the manner of the reser of basket willow.

"The most remarlathle and probalily the most valuable phant of the nette fimily groper is that which produces the

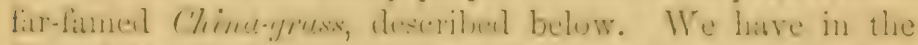
Unitud States an indigenons precies of the sume enus to

to be rejected must be britle, with short cells, not much hardened or wot strongly adhering togrether. Flax and hemp are, in our own country, the best specimens of these favorable conditions, but we have other plants nearly, if not quite as well adapted to the manufacture of useful fibre; and other countries show that nature has not been stinted in her supply of materials eapable of meeting one of the first wants of mankind.

"If we have been successful in communicating a clear idea of these conditions, the ready conclusion must be that differences in degree, cren in the same plant, under varging circumstances, must frequently occur; the wood may become harder and greater in anount, the bast weaker and less in quantity, and the necessary inference might be drawn that judgment and skill in the culture of the fllants would favorably modify these conditions. Experience, in adrance of anything like an accurate knowledge of plant structure, has shown that this is true, at least for our common fibrous crops. Single stalks of hemp or other fibrous plants allowed to grow at a distance from each other, or from other plants, would furnish but sorry specimens of filse, if, when collected, they were managed ns the results of an ordinary crop. $\Lambda$ single plant invariably shows a hard woody stem, and a coarse fibre in tho lark. But when a number of plants are grown in a small space, every one knows that they grow longer, and are more slenler than when left to thenselves. In this way the strength of the wood is much diminished, and the fibre of the bark, if less abumdant, is finer, and possibly longer. If the plant has a tendency to branch, this is prevented, for the neat preparation of fibre from a branching stem is no ensy matter.

"The close cultivation of cotton, okra, and other plants, which we are accustomed to see separated from ench other, wonld probably show a fibre in the bark far more capable of treatment by the ordinary processes than would be suspected by most persons. A knowledge of correct principles is here of the grentesi actvantage, when wew materials are coneerned. The influence of the soils and the detuils of the treatmeut of the crop are beyoud the bounds of this article." 
which the China-gress belongs, but it seems never to have been properly examined. Of our species of true nettle, one, which is an introduced plant, has been employed in Europe for fibres. In the Western States, before the cultivation of the soil for anything exeept articles of fool had been commeneed, nettles of spontameous growth were used as a substitute for flax, and we have often seen persons who remember the time when shirts were made from nettles. Tre camnot learn whether attempts have been made to cultivate these plants."

Cluina-grass or grass-linen, sometimes called Culoee or Rlee lemp), is obtained from the snowy nettle, the Urtice or Berhmerice nivere, a plant abundant in China and Inclia, and which, it has been proved by experiment, can be cultivated without difficulty in the United States. It was described early in this century, by Dr. Roxburgh, under the name of Uitica tenacissima. It derives its specific name from the white color of the under sicle of its lenves. Although for many ycars gradually increasing in commercial importance, it was not until the London Exhibition of 1851, that the fibre of this plant obtained the notice of the public generally. It was then exhibited in every condition, from the crucle article to the woven falbric, showing a fibre of such beauty and strength, that three prize medils were awarded to different persons for specinens in the prepared state. Of the value of the filure, no better evidence can be given than that of Dr. Royle, who states that, as imported into England, it has sold at from $\$ 300$ to $\$ 400$, and even $\$ 600$ a ton. In respect of strength, it has been proved by numerous experiments that it sustains a weight always much greater and sometimes nearly double that of the best Russian hemp. The eloth made from the fibre, known as grass-cloth, is not unlike silk in appearinse, and has a softness and strength distinct from that of the fabric of any other fibre.

The plant seems to be casy of cultivation, and three crops a year may be taken at intervals of about two monthe, the second growth yielding the finest fibre. The truatment of

* Dr. Scheeffer, Report of Patent Office, 185?, Agricultural, p. 387. 
the crop varies, but in seneral resembles that of hemp ('Xcegt that the filmes are preded from the stalks by hami, and then expresel to the dew ly night ame the sun by day, avoiling ram. In othereases they are sonker in line-water, or briterl in a slightly allialine sclution; sometines agatin the fibre is spon and even woren before it is bleached. The plant is now cultivated largely in rarions parts of India, and bids livir to boome it most important article of commenes. Areber, in his "I'ognlar Ecomonic Bonany," olserves of it: "At present our mole of extrateting the fibre is unt sufleciently perfect, but we are maling raphal impurenents, ami may houpe that grass-linen, erual in quality wh that of China will are loner be ats cheaty and plentiful at that made from flax."

In the Lonton lixhlibition of 1851 were exhibited fibres

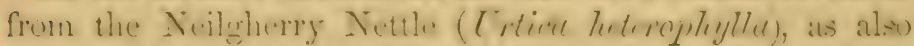

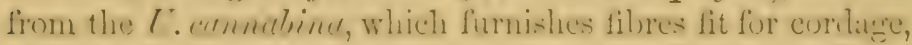

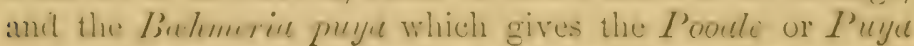
flax of Nepaul and Sikkim.

There is a variety of this plant (Trtice Zueceifere) incligenous to Cuba, where it is known as Chichierete. It is chichly found in the Western deprutments of the island, crowing in rich soils. The stem rises to the height of from nine to ten feet, and is about two inches in thickness, coverenl with prickles. Its leaves are green on their upper surfiue, but galer beneath, with neodle-like spines marking their veins, rendering contant with the plant most distressing. Its bark yielits a stromg tibre, which is used locally for corratare

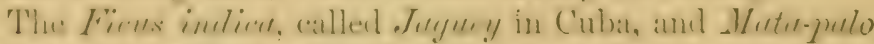
(Kill-tres) in Colltal Ameriea, som-times primarily parasitic, often attaining giguntie siz", somling lown trunk after trunk to the gromut like the banyan tree of lumlia, and always

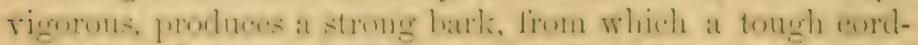
age of gand quality and hat little aflected by the weather,

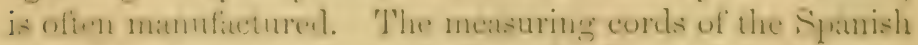
survejors are gencrally mikle from the fibres of the jeguey. 


\section{II.-The MaLva, or Mallow Family.}

The plants of this family are known throughout the world for their excellent fibres. They are not only very numerous, but differ very widely in appearance. Some are herbaceous, while others are arborescent. Both varieties produce useful fibres.

1. The Mohoe, or MLohout tree, (Hibiscus arboreous of Seeman,) is abunclant in many parts of the tropies near the sea, and for considerable distances up the rivers. It grows to the height of from sixteen to eighteen feet, and throws out large flowers of a yellow or saffron color. Its bark is tough, not much, if at all inferior to hemp for many purposes; the fibre is naturally white, and of a soft, filamentous texture, and apparently admirably adapted for the manufacture of paper. It is now used locally for making ropes, which are in no way inferior to those of hemp in strength and chrability. In Central America, the trunk of this tree, which is noarly as light as cork, is used in making rafts for floating logwood, etc., down to the sea.

2. The Hibiscus tiliaceus, or the Mrijagua of Cuba and Central America, also produces a valuable fibre much used for ropes. It is little affected by moisture, and lience is chosen by surveyors for measuring lines, ete. It is found usually near water-courses and the sea-side, and is consequently sometimes called Mrajagua de playa. This plant is diffused over the tropical and sub-tropical regions of both continents.

Sir J. E. Snith describes this as "One of the most common trees in every part of the East Indies, thriving in all sorts of situations and soils, and cultivated for the salie of its shacle, even more than for the beanty of its flowers, in towns and villages and by the road-side. $A$ coarse cordage is made from the bark; the wood is white and light, useful for small cabinet work, and the mucilage of the whole plant is applied to medicinal purposes."

3. The Sum, or Sunnee hemp of India. There seems to be two kinds of fibres produced in India under this name; 


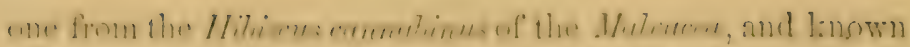

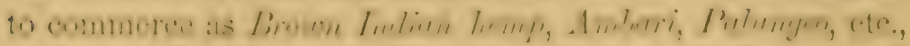
and the other from the Croteleriat juncea, of the natural

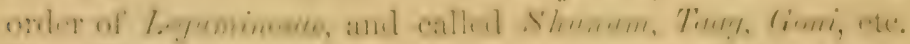
The Ilibiscus cannabinus is not confined to India, but is epmally fomm in limall and tropheal America. In Cuba it

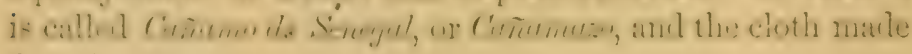
from it coletu.

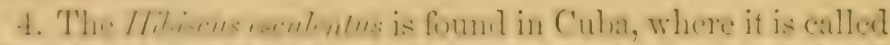

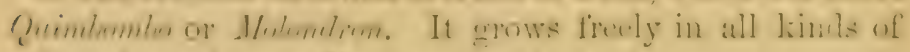
soil, and problues a fibre aplylieable to the satme nees with the flax of Eumpe. It is linown in the Cuited states as ctme and it is believent if the plants were grown checly

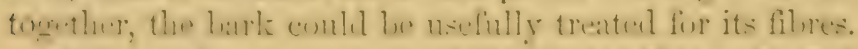

Of the mal racesous plants of the I nited States, Dr. Sclacefor obsures: "A great many of" these in the southwest are pondarly unkmon, but a trial of their capacities will be a great public service. Our great staple, the common cotton, is oldained from the wool ont the sererl, and is therefore not a hark libre; lut as the cotton is a malracents plant, its hark might be supurseal to be a goonl fibre. This has ben verified, as shown in the Patent Oftice lieport for 15.54. But the cotton in other regions erows to be it tree, and if we allow it to promluse sarels ahmulantly; as it must rbo, to aftort an

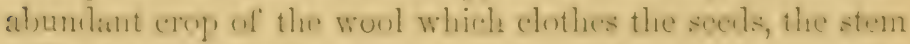
will, as a matter of course, become hard and woody. No one ean imagine that thre would be protit in cultivating the (e)tion fin the fibre of the bark, at the surerifice of the more

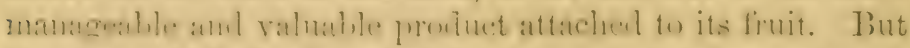
the ofor, which is only rasisel for its esculent, immaturescerl-

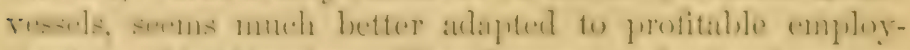

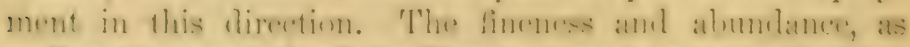
well as the streagth of the titure, are such as 10 remiter ex-

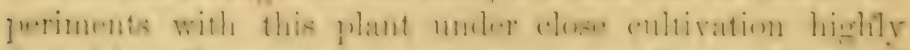

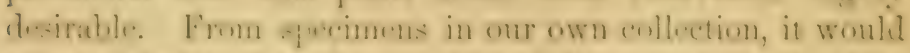

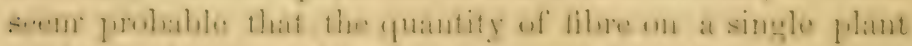

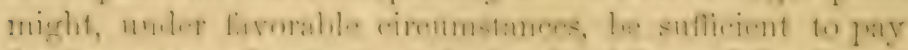

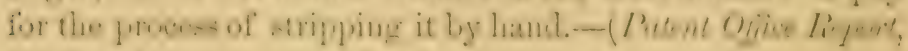
1859. Agricullural, p. 387.) 


\section{III.-Tilia, oR Lime Tree Fanily.}

The principal varicties of this fimily are found within the tropies, forming weed-like plants, shrubs, or trees, with hanclsome, usually white or pink flowers. I small number are peculiar to the northern parts of both hemispheres, where they form timber trees. Among these are our lime or linden (vulgarly, bass or bast-wood) trees.

1. The inner bark of the linden (Tilia Europea) is tough and fibrous, and from it are manufuctured Prussian mats.

2. Jute, or Jute hemp, is produced from the bark of a member of this order, the Corchorns capsuluris, which is cultivated to an immense extent in India, particularly in Bengal. It is also found in Brazil, whence small quantities are exported. It is an annual plant, growing from twelve to fourteen feet in height. The fibre, which has of late years become so generally used that it rivals flax and hemp as a commercial product, is usually about eight feet long, fine, and of a remarkably satiny lustre. It will not stand ret well, and hence is not adapted for cordage or canvass that requires to be exposel to the weather. In India it is chiefly used in making coarse canvass, called gummy, of which bags and bales are made for packing raw produce. In England it is often mixed with hemp for cordage ; and is even mixed with silk in the manufacture of cheap satins, in which it almost defies detection. Its principal use is in making conrse cloth for bagging, and in making the foundations of cheap carpets, mats, ete. The amount of Jute hemp imported into England from the British East Indies, for the year 18505 , was $520,96 \pm$ cwts., valued at $\$ 2,159,830$. The amount imported into the United States for 1860, at the custom-luouse valuation, was upwards of $\$ 2,000,000$.

Besides direct importations, a large quantity of gunny cloth is sent from the East Indies in the form of envelopes, for other materials, such as nitre, coffee, etc. Owing to the great cheapness of the gunny, the bags are rarely uset more than onee before they fall into the lands of the rag-merchants and paper-maliers. In this condition they constitute 
the cheapest paper-stock to be found in the market. The demand fir it, howerer, has not been extensive, even at low priars, as it is imposible to lileach the fibres suflerently to remler them servicablo for the mamnficture of white paper. This is owing to the fact that the bark of the tree producing the gunny, contains a large quantity of humic and cremic acils, togither with some nimeral bases and sone tanuin. These sulstances rapinlly nentralize and destroy almot any bleaching agent which ean be applied. The use? of gumny is, therefore, wholly restricted to the manufacture of brown wrapping and envelope papers.

8. The best and whitest rope neer in the Isthmus of Panama and many prats of Sonth and Contral Ameriea is nowle from the fibre of a member of this family, the .1pilme Tilmentum or Cintea of the natives. In Culat there are a number of luants and trecs of this fanily known under the name of Guivesos.

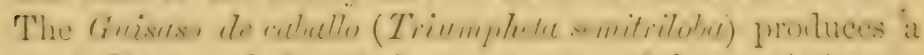
good fibre used for clnth, ropes, ets. Oiher varieties are said to equal it in this respect, but the best fibre is obtained

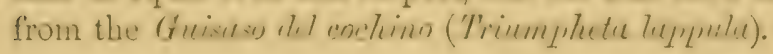

\section{IV.-Yucca, Liliacea, or Liliy Famiry.}

This is a large and useful fomily of plants. Some are showy gurelen flowers, such ats tulipes, lilies, tulreroses, ete., while others produce medieines, amolog which the alce is confingous. Others still prenhee fibres of good yuality, and to these we emfine curselves. Five variedies of these,

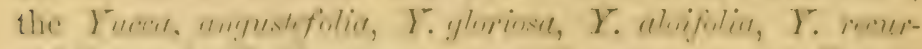

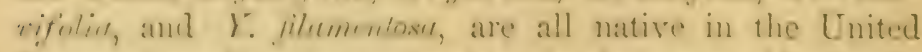
States, abomaling in the regions bordering on Mexien, in

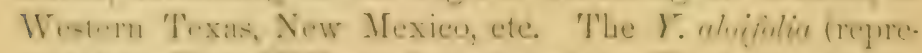

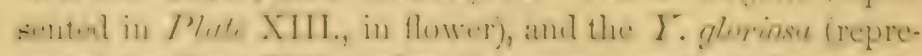
sated in /lint. XIV., before tloweringe, are both frepuently

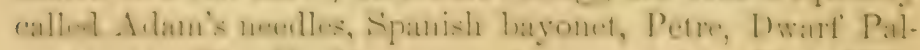

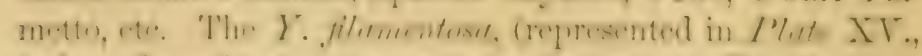
before floweringe) is communly lizuwn ats liars gras,

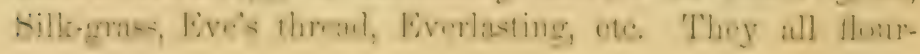


ish in the poorest soils, and might be propagated in almost all parts of the United States. Nutall, in his citalogne of North American plants, mentions the $Y$. filamentose, and angrustifolic as found on the banks of the river Missouri from the confluence of the river Platte to the mountains. The Y. gloriosa, he adds, is called Petre by the Mexican Spaniards, "and is used for cordage, ropes, etc., as well as for packing cloth, and is extremely clurable." Of the $Y$. filamentosa, Elliot, in his Botany of South Carolina, says, "It appears to possess the strongest fibres of any vegetable whatcver, and if it can be raised with facility, will furnish a valuable article of domestic economy."

That all these varieties can be made available by the new machinery referred to in this memoir, may justly be inferred from the uses to which the kindred plant, the Phormium tenax, which yields what is known to commerce as $N e$ ow Zealand flax, is applied. Plate XVI. represents this plant in flower. It can scarcely be distinguished from the yuccas of our own country, by the uneclucated eye. The fibre is now extracted from the long lenves by drying, maceration, and hackling. The coarser qualities make good ropes, and very fine linen is manufactured from selected fibres.* Specimens of hemp equal to that called New Zealand, was sent to the London Exhibition from the Behamas, manufactured from the Yucca serrulata.

Morgahce, Africun IIemp, or Bow-string Hemp fibres, were exhibited in the London Exhibition of 1851. They are prepared by hand from the leaves of a plant of this order, the Sanseviera zylanica, which is found over the tropics of India and Asia.

* In the report of the great Exhibition in London of 1851, it is stated that the mode adopted for extrneting the New Zealand hemp is as follows: "The plants are soaked for two days in water, then twisted into hanks, and beaten with a mallet, the extraneous matter being washed out, leaving the fibre." The plant producing this hemp has been acclimated in the South of France, and in Algeria. It has also been introduced into South Carolina, and other Southern States, where it flourishes and propagates itself in a wild state. 


\section{V.-Leguminosae.}

The flants of this oriter are ahnost innmorable. De Cimlulle gave 2.860 species as known in his day, of which upwarils of 1,001 were preculiar to tropical Anerica, and 4.2 to the Eatst Indies, where a number of vitrieties are valued for their filnes. I an not aware that any of them have been nacel for the production of fibres on this continent, except perhaps in Brazil.

1. Sun, Shumum, Tieng, Janmpum, or Bengal hemp, to be

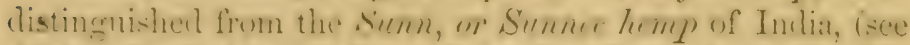

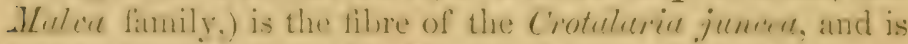
a valuable substitute fior Russian hemp. It is coarser in iquality than the Jute lempl, lut better capulsle of withstameling wet. 'The natives of Intial mannfateture it into all limels of ropes, pateking eloths, sacks, nets, ete. In oreler to impore the fibre the platuts are sown as closty as possible, and thus grow to the height of about ten fect. Dr. Buchanam C.Jourm 1/. V(1. I., 1. 226-7, 291, etc.) states that the flint thrives best on poor sandy soil, but requires to be abmodantly watered. When cut down, it is spreal in the sm ancl irient, the sacels beaten out, alter which it is tim $11 \mathrm{p}$ in large bumlles an? stackenl muler sheds. When wanted, the stems are materated from six to eight clays, or mutil the bark soparates realily from the pith. They are takin up in lamblals, beaten on the gremml, and washed until char of the pith, after which they are drient, and beaten with a stick to separate and clean the fibres, which are then reanly for spiming. If takn green, and worked by Mr. Mallory s proares, the fihe wombl be white insteal of hown, and probably

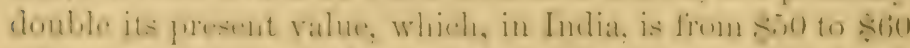
ferten. In awe of the plant is estimateal to produce about $600 \mathrm{lbs}$. of the cleaned fibre.

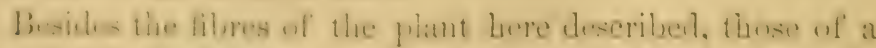

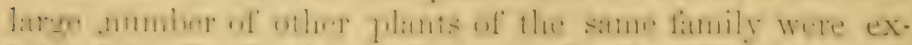

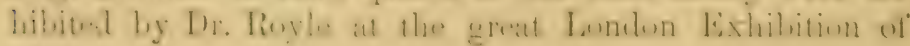
1851.

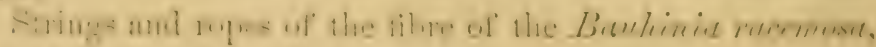
called l'atwo, from BLagnepore. 
Tereum fibres from the bark of the Calotropis giganted. Fibre from the stalks of Parkinsonia aculeata.

I'ules corlage from the fibres of the inner bark of Butece frondosi (a fine tree.)

Duchai hemp, fibre of Aschynomene cannabina.

An arborescent member of this family, Lonchocarpus inure, is found in Cuba, where it is called guama. It grows to the heiglit of from thirty to forty feet, and is nine inches in thickness. Its bark furnishes good fibres used for cordage and cables. There is another variety in the island known as Guama del costa (Lonchocarpus siriceus.)

No doubt most, if not all of the above fibre-producing plants are diffused over tropical America.

\section{Asclepia or MilKweed Fanilu.}

The ordinary milk-weed or silk-weed (Asclepias comuti) is so well known as hardly to need a description. The abundant and beatutiful "silk," on the seeds in its porls, howerer, is susceptible of but few useful applications, inasmuch as the hairs are cylindrical and perfectly smooth, and therefore incapable of laking that hold on each other necessary to being spun into thread. The bark of the plant nevertheless contains a fibre, which was once regarded as of sufficient value to induce its introduction into Europe, and its cultivation there. IJere, however, the plant has been entirely neglected, although it appears that a patent for extracting its fibre was granted in $183 t$ to Mrs. Margaret Gerrish. The fibre is long, nearly as strong as that of hemp, but firmer and more grlossy, while the quantity from a single stalk is nearly the same. Dr. Schreffer says of it, "The culture of this plant is saicl to be without difficulty, and almost every one has observed it growing even on the poorest soils. As it is perennial, with strong roots, successive crops might, for a long time, be oltained from one sowing of the seeds. * * The fibre may be rankel between that of hemp and of flax for textile purposes, while, if the commereial demand for such 
uses were not snfliciont, its cultivation for paper stuff, at once, might prove remunerative."

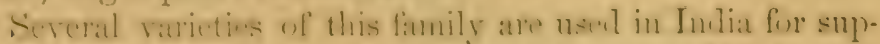
flying tilurs. One, furnishes the rery tentering fibe known

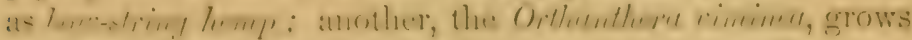

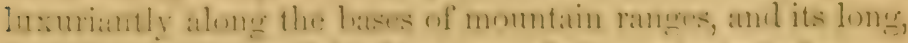
siraight, sleuter, and lealless stems fit it particularly for supplyiug materials for cordage.

Tremm-ner is the natue given in Bengal to the fibres of a

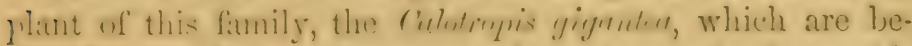
liever to be the mest tenacions of any known in the world. (Sec 'Tables, p. 22).

\section{Miscellaneous Plants.}

De-citles the rarious plants of the sereral families already icscribet, there are numerons individual plants which produes libres, lut which it would ocenpy toe much space to notien in letail. Anomg these may be mentioned the Girat-

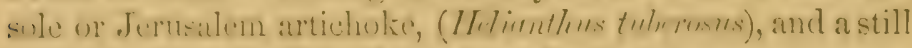
more fumiliar member of the same fantyly, the common sunfluwer (HI limethus ammuns). It is sain that the latter yields four kints of filne of diflerent qualities and thicknesses. A jatent was chtainerl in England in 1siof, for extracting the fibres of this plant by machinery.

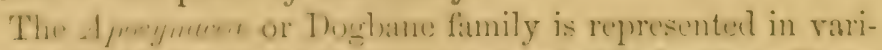
ons farts of the workl ly plants renarkable for their fibres. Two of these in the I nited States are rathel well-known for their melicinal properties and their fibres. One of these, the "Inlian lu:ml," (1, enmulimmm) has its properties representerl both by its common and its botanical name. Experiments on its cultivation are desirable. 
I'ACH: :DI

! $1 \therefore 1 \%, \quad 1$. 

PLATE II.

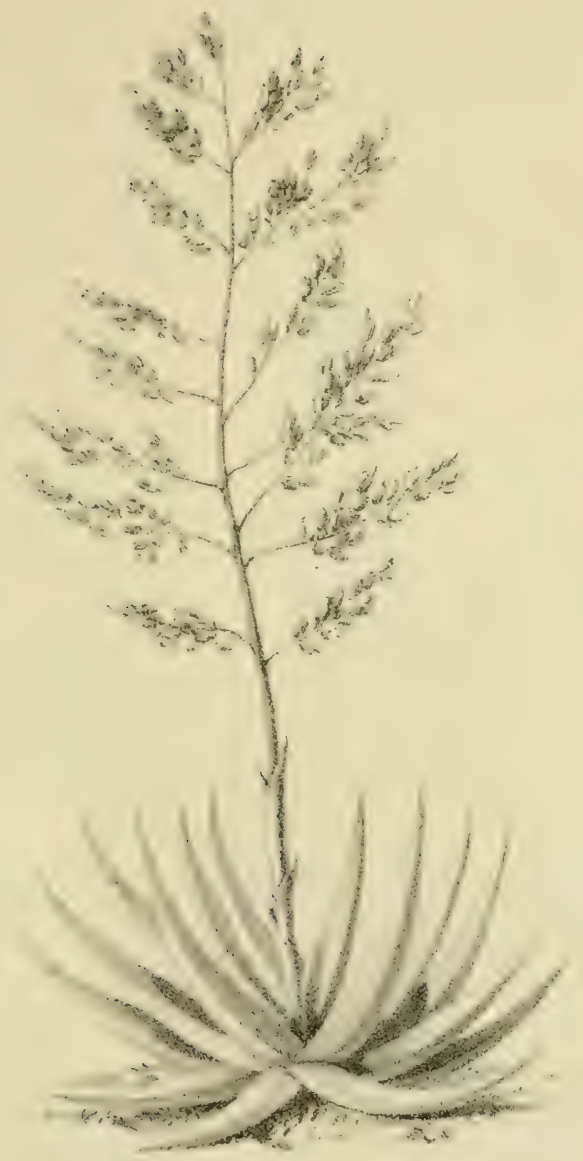

FUREREA GIGANTEA. 



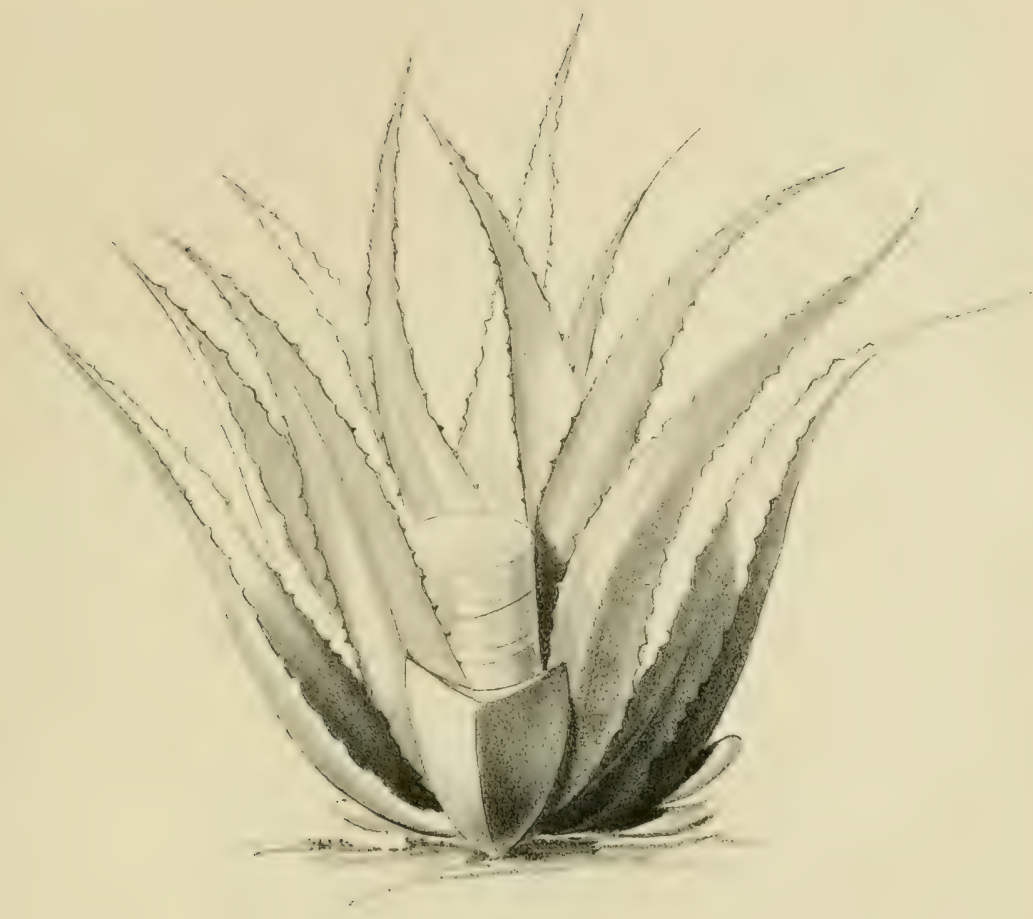

AGAVE MEXICANA. 



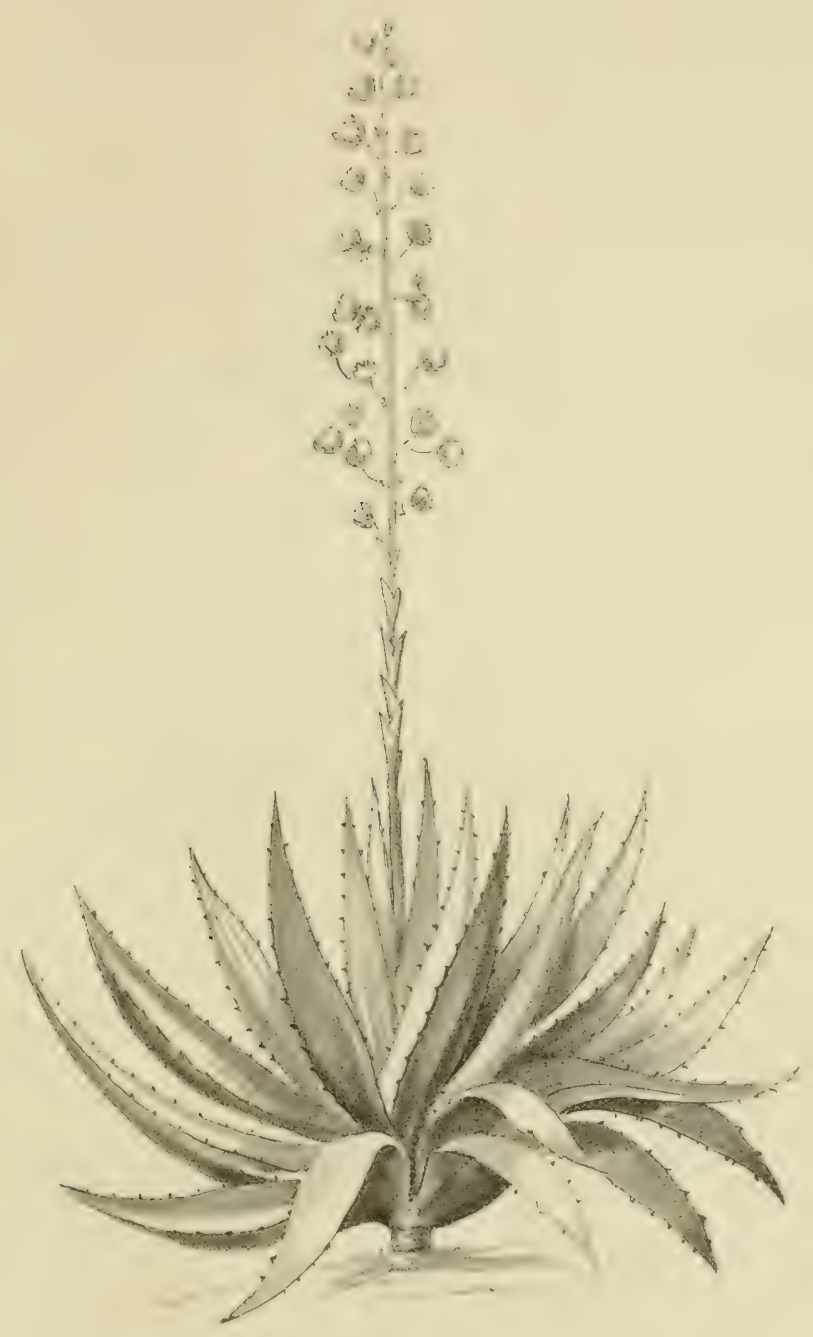

AGAVE AMERICANA.

(CENTURY PLANT) 



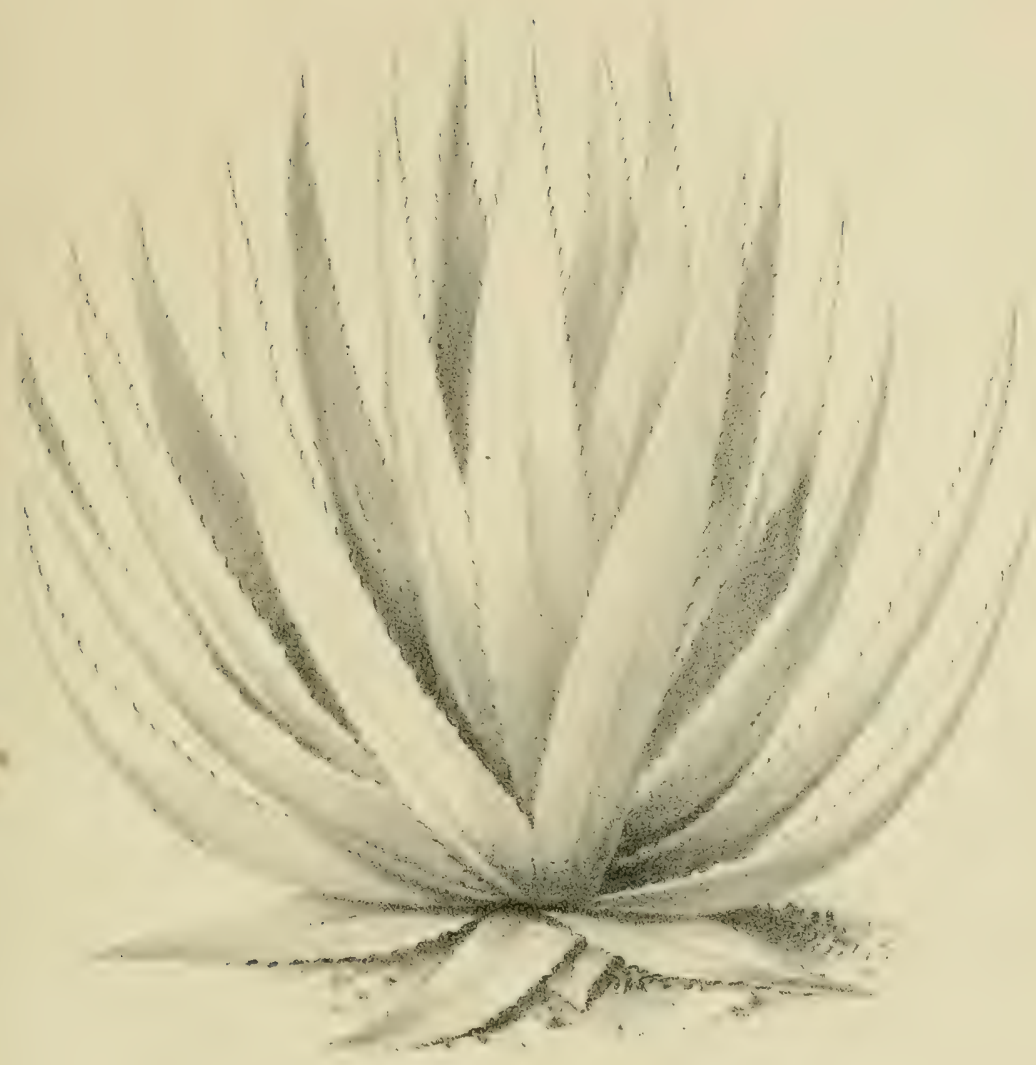

AGAVE VIRGINICA. 



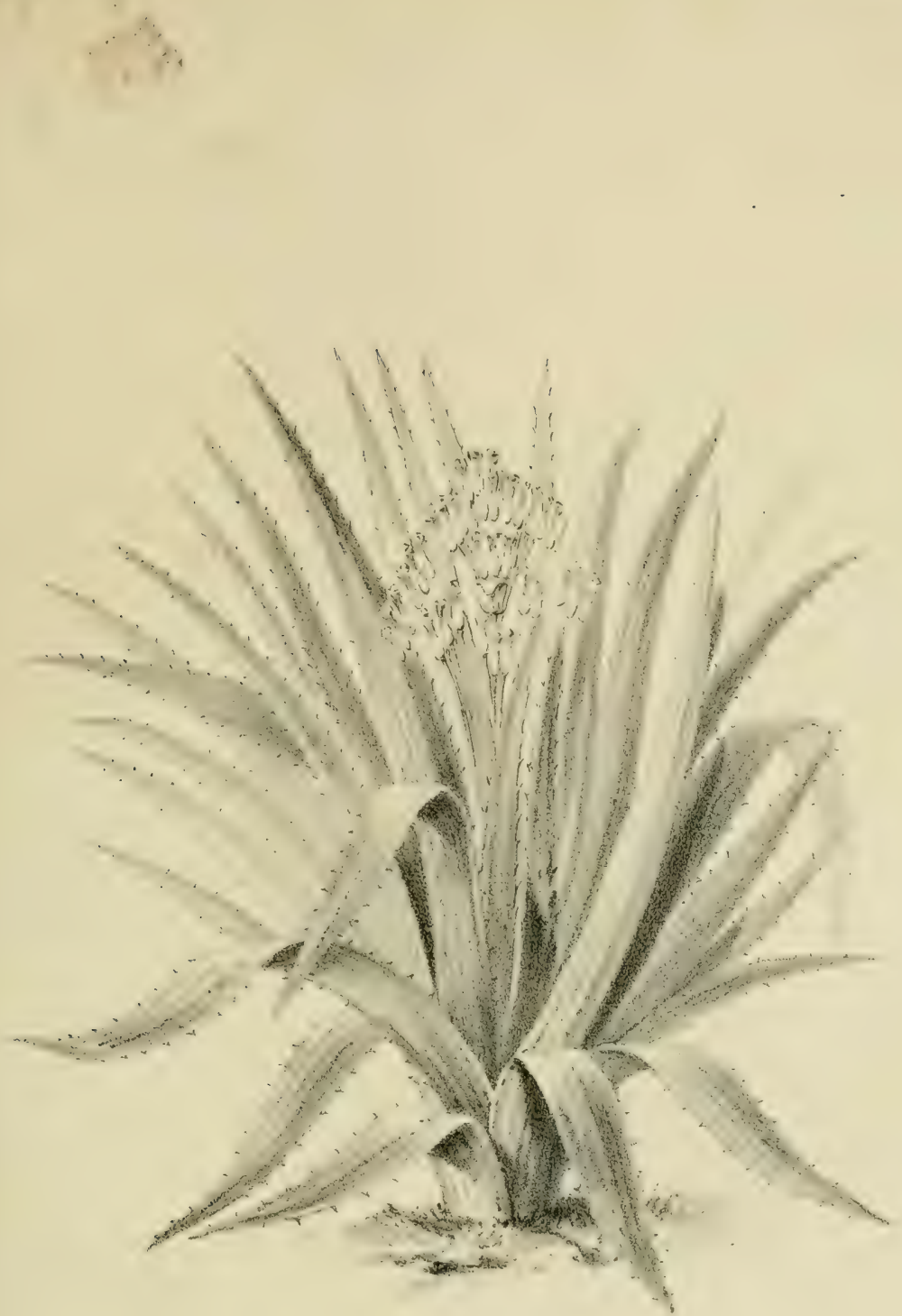

BRROMFIA SYLVESTRIS OR PENGUIN (WILD PINE APPJIE) 



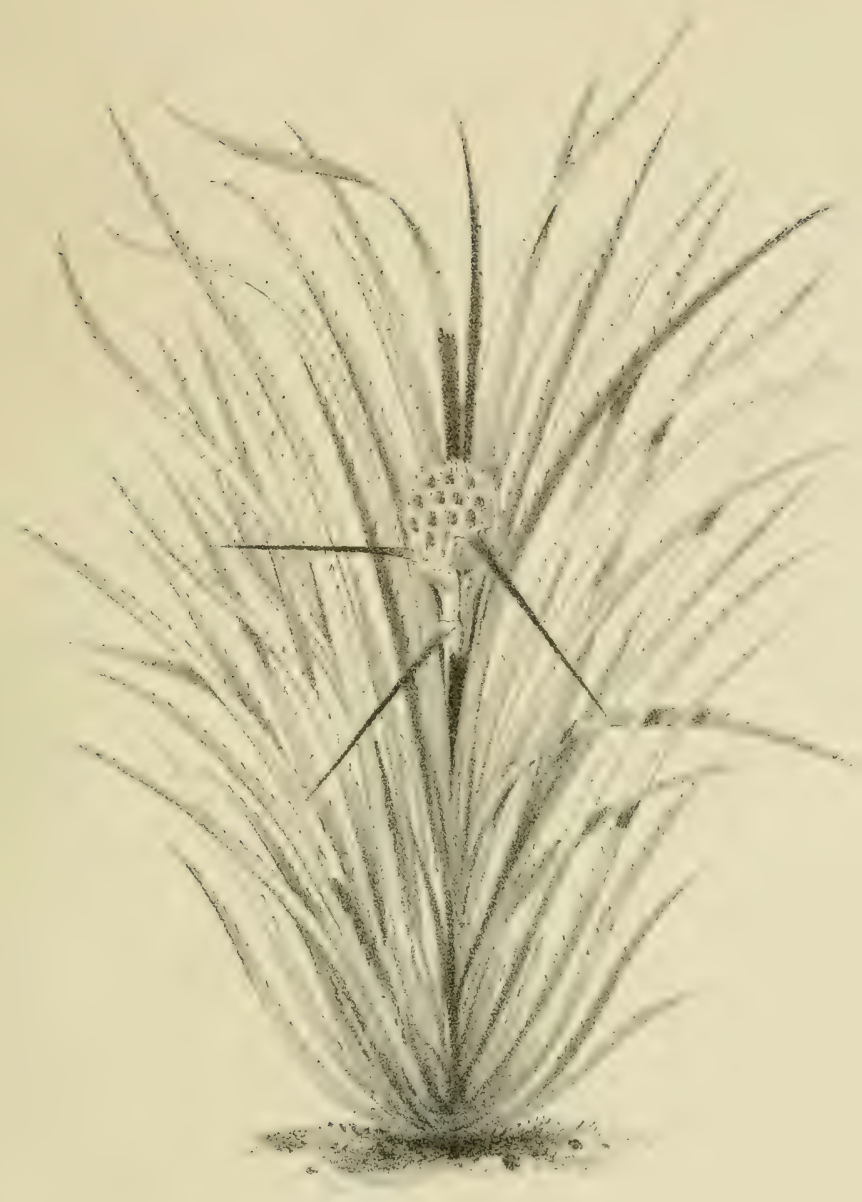

BROMELIA - KARATIS 




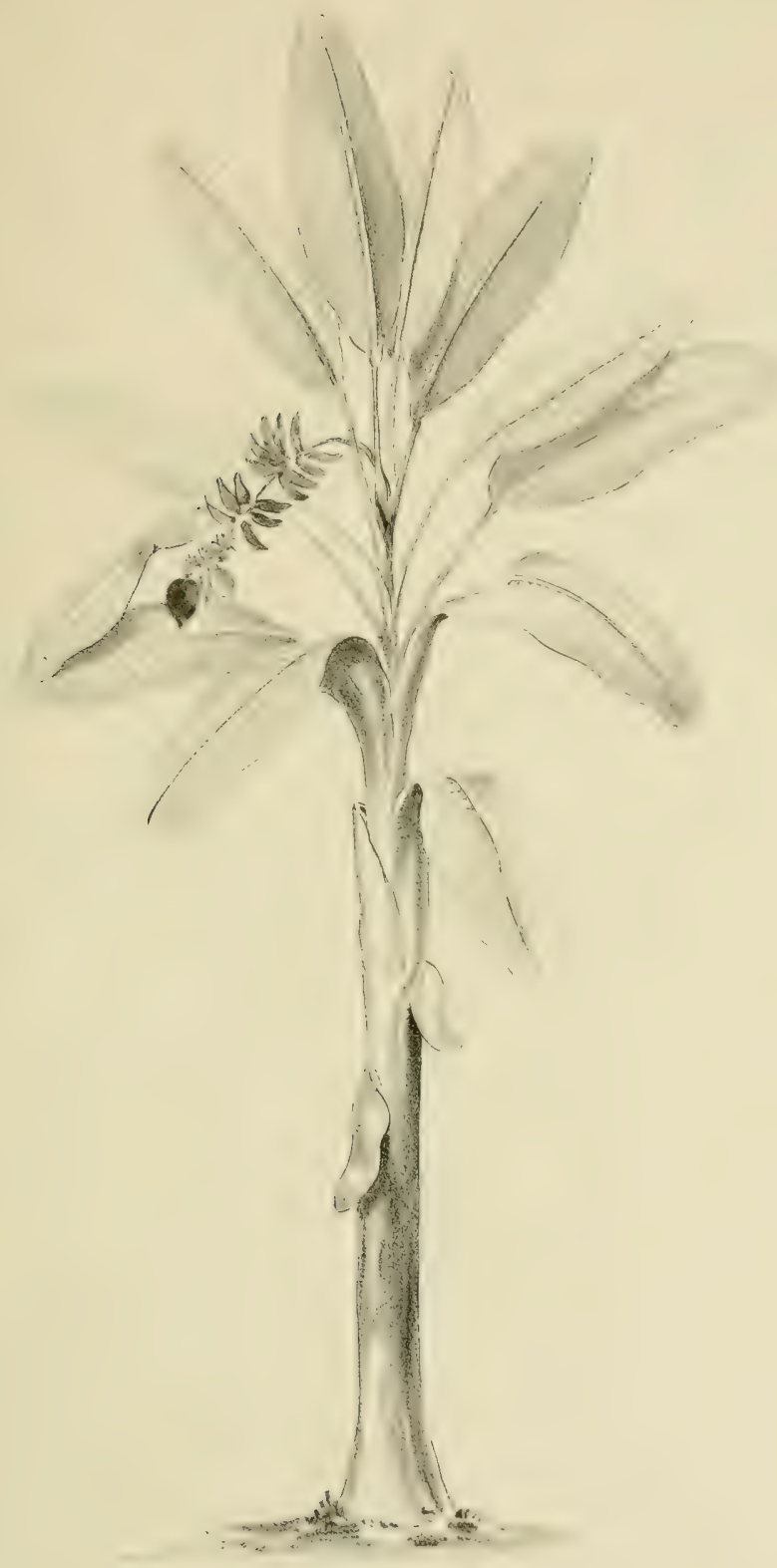

MUSA ROSACEA.

(BAITANA OR PLANTAIN TREE) 



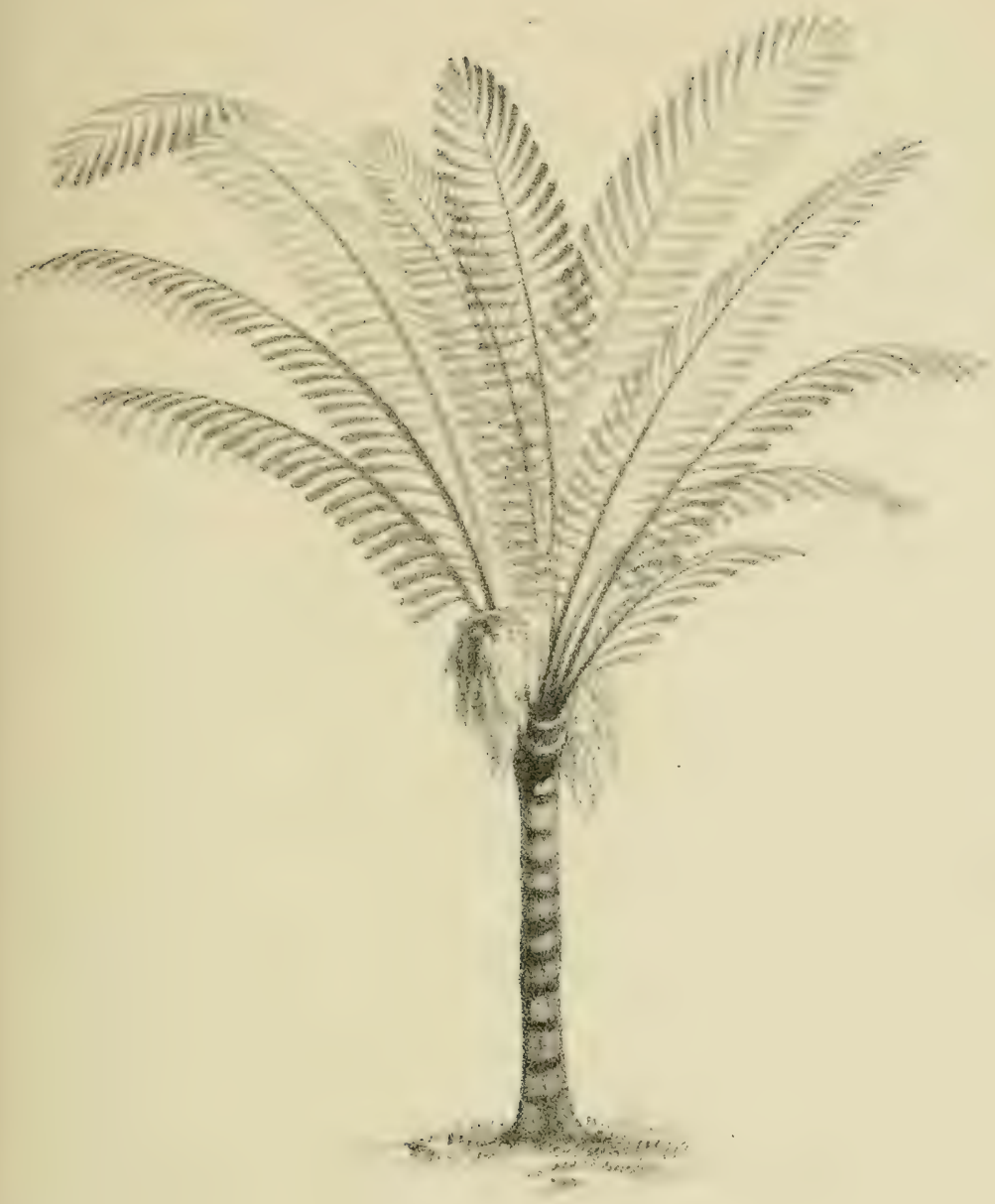

ARENGA SACCHARIFERA 



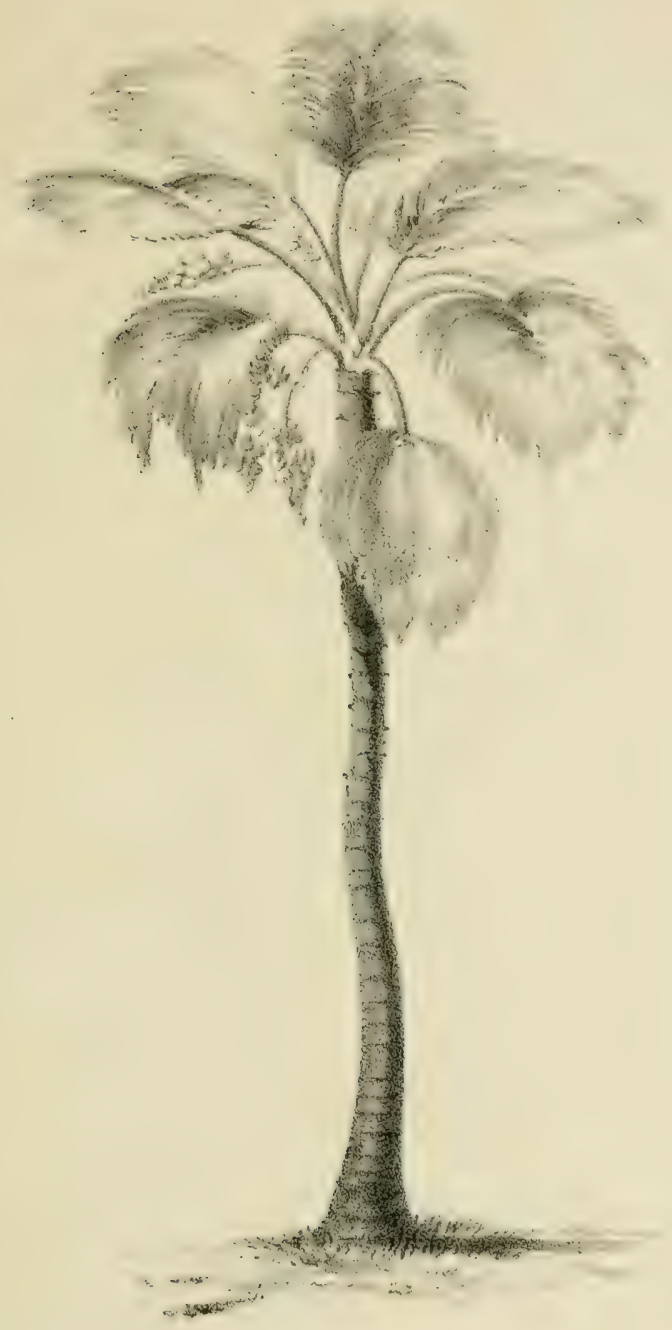

BORASSUS F'LABHLLTFORMLS. 



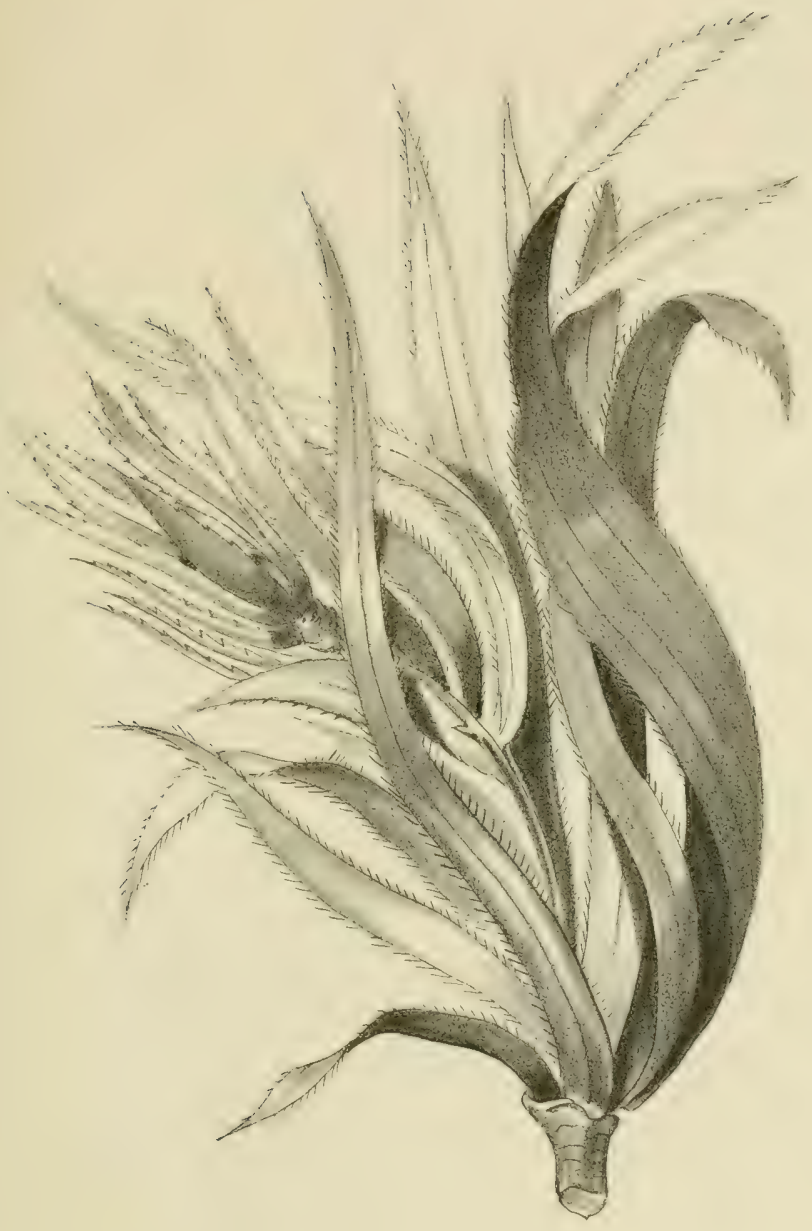

PANDANUS ODORATISSTMUS 



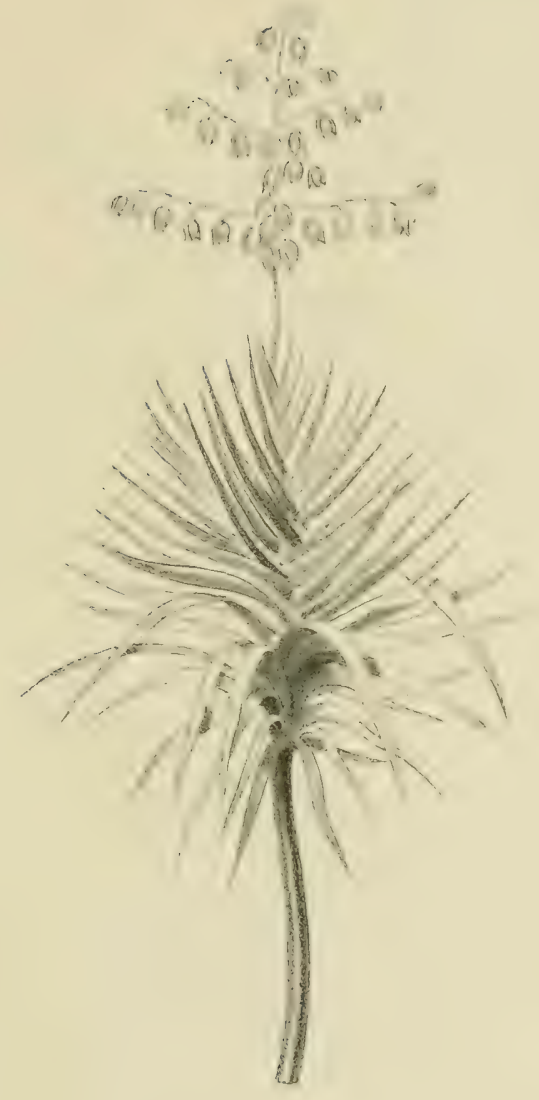

YUCCA AIOIFOTIA 



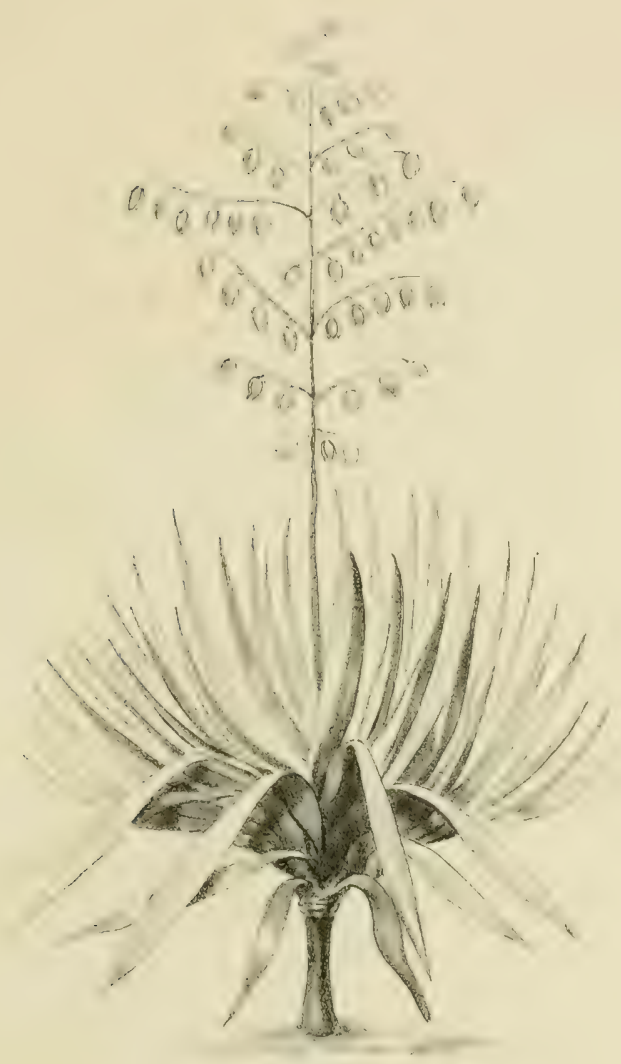

YUCCA GLORTOSA

(SPANISH BAYONET) 



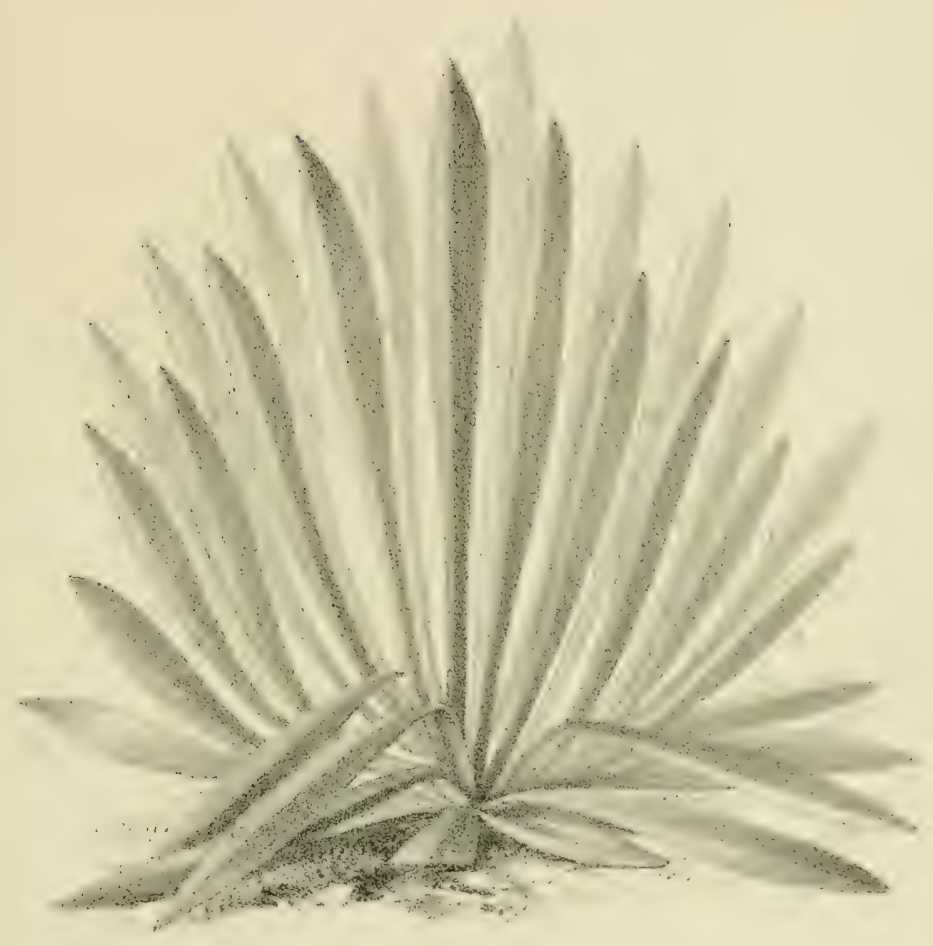

YUCCA FILAMENTOSA 



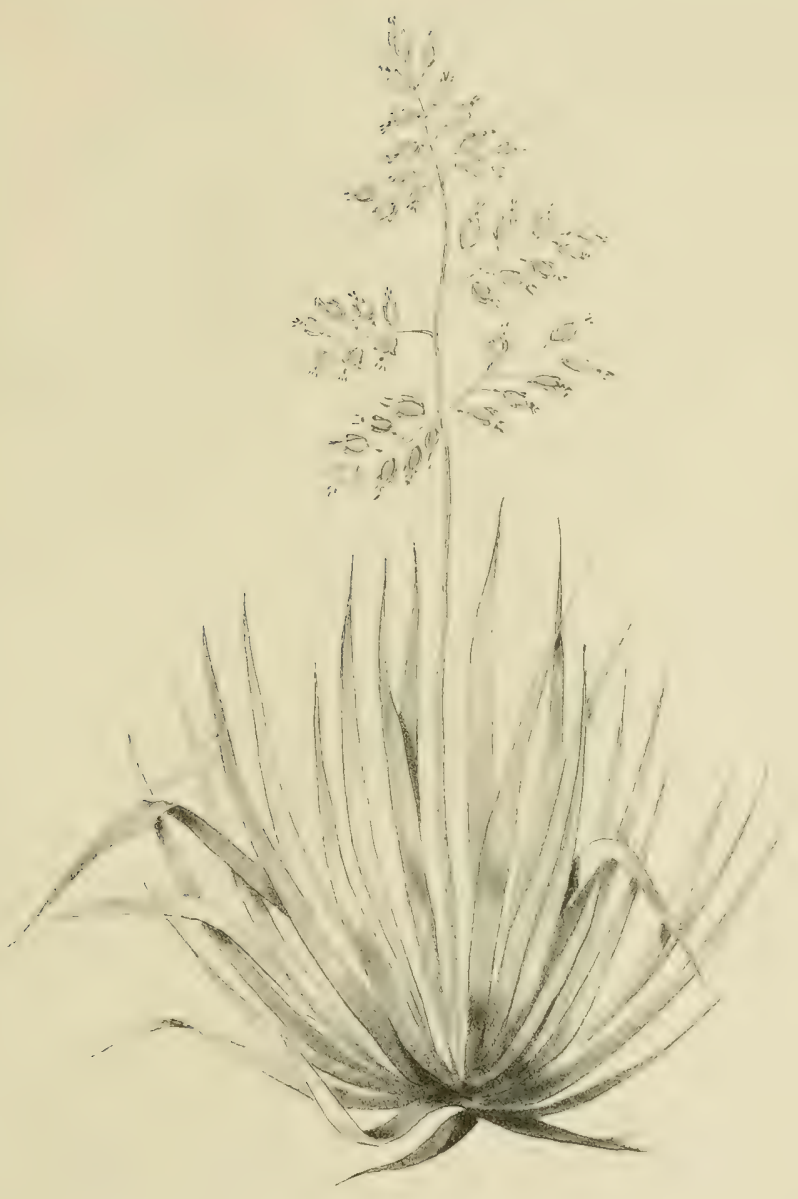

PHORMIUM TENAX .

(NEW ZEALAND HEMP) 



at)

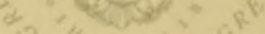

(2)

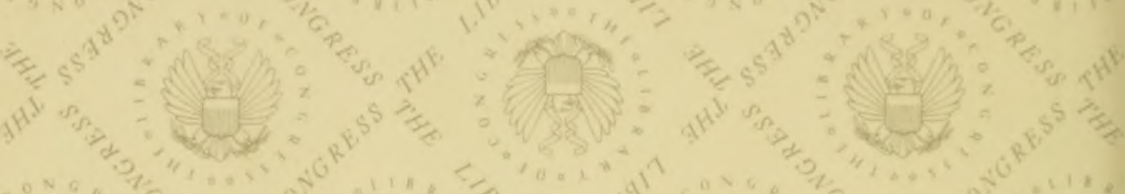
and

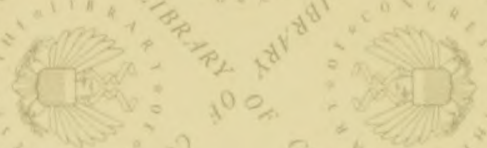

\section{ton} $\mathrm{o}^{*}$

(6) Liling

$x^{3}+s_{0}=\sqrt{2}$

(i)

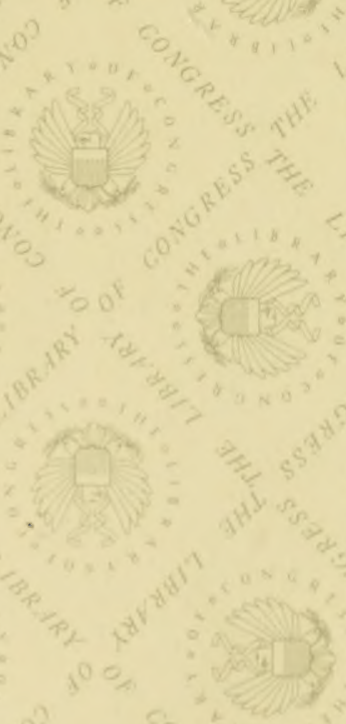

$\operatorname{lin}_{n \rightarrow+}$

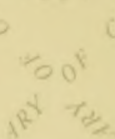

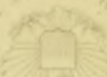
$2 \int^{2}$
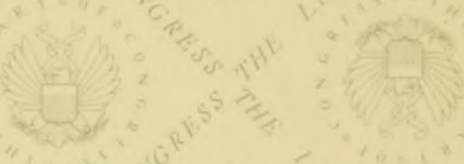

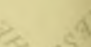

$\left.x^{3}\right)^{3}$

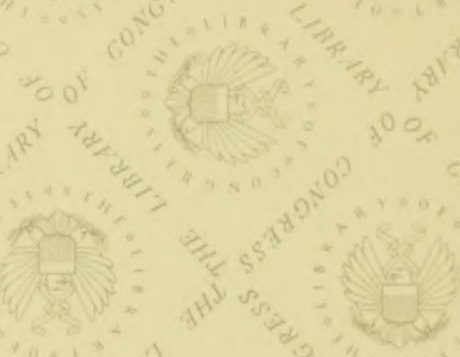

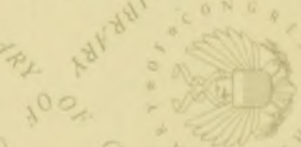

ro
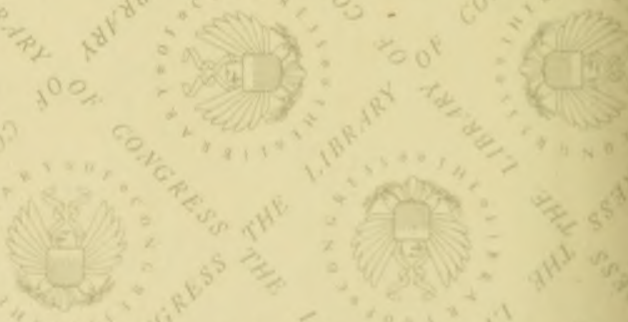

5

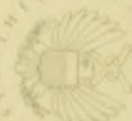


200 (2) 7

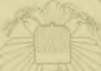

100

\section{은?}

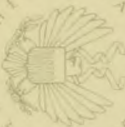

2

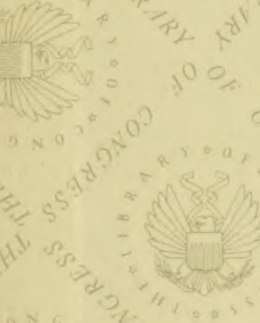

(4) $3: 100$

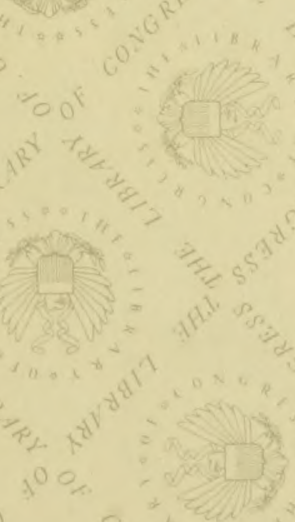

$b_{2} x^{3+3}$

$x^{0} \mathrm{O}$<smiles>c1ccc(C2CCCC2)cc1</smiles>

in $i$ in

(1)<smiles>C1CC2CCC(C1)C2</smiles>

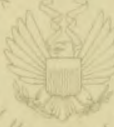

\section{$20 \ln ^{2}$}

100
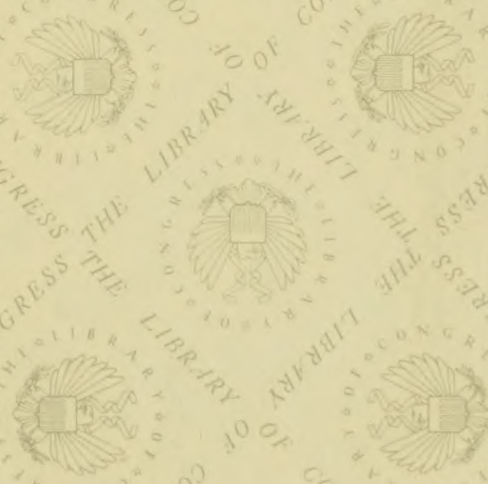

ating 


\section{LIBRARY OF CONGRESS}

|||||||||||||||||||||||||

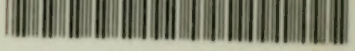

00009314969 